\title{
Design of a Lifecycle-Oriented Environmental and Economic Indicators Framework for the Mechanical Manufacturing Industry
}

\author{
Andrea Barni $^{1, * \mathbb{D}}$, Claudio Capuzzimati ${ }^{1} \mathbb{D}$, Alessandro Fontana ${ }^{1} \mathbb{D}$, Marco Pirotta $^{1, *(\mathbb{D},}$, Saara Hänninen ${ }^{2} \mathbb{D}$, \\ Minna Räikkönen ${ }^{2}$ and Teuvo Uusitalo ${ }^{2}$
}

Citation: Barni, A.; Capuzzimati, C.; Fontana, A.; Pirotta, M.; Hänninen, S.; Räikkönen, M.; Uusitalo, T. Design of a Lifecycle-Oriented Environmental and Economic Indicators Framework for the Mechanical Manufacturing Industry. Sustainability 2022, 14, 2602. https://doi.org/10.3390/su14052602

Academic Editor: Ben Amor

Received: 30 December 2021

Accepted: 21 February 2022

Published: 23 February 2022

Publisher's Note: MDPI stays neutral with regard to jurisdictional claims in published maps and institutional affiliations.

Copyright: (C) 2022 by the authors. Licensee MDPI, Basel, Switzerland. This article is an open access article distributed under the terms and conditions of the Creative Commons Attribution (CC BY) license (https:// creativecommons.org/licenses/by/ $4.0 /)$.
1 Department of Innovative Technologies, University of Applied Science of Southern Switzerland, Via la Santa 1, CH-6962 Viganello, Switzerland; claudio.capuzzimati@supsi.ch (C.C.); alessandro.fontana@supsi.ch (A.F.)

2 VTT Technical Research Centre of Finland Ltd., P.O. Box 1300, FI-33101 Tampere, Finland; saara.hanninen@vtt.fi (S.H.); minna.raikkonen@vtt.fi (M.R.); teuvo.uusitalo@vtt.fi (T.U.)

* Correspondence: andrea.barni@supsi.ch (A.B.); marco.pirotta@supsi.ch (M.P.)

\begin{abstract}
As a result of the worldwide depletion of natural resources, increased energy use, and environmental, economic, and social imbalance, organizations are working to identify the proper strategies supporting the continuous reduction of their impacts. While this trend is fundamentally agreed upon in the literature, several manufacturing industries still fail to identify which elements most influence their contributions to the impact of sustainability and how to easily manage the calculation of these effects within a manufacturing system. The purpose of this article is to incorporate sustainability practices into manufacturing by developing a set of key performance indicators (KPIs) for assessing and improving environmental and economic management practices at the corporate and production level. The definition of the framework began with in-depth research of the leading indicators and framework types in the literature, integrating the most exploited industrial standards to make them easily acceptable in the industrial domain. Then, to provide a broad view of company behavior, the framework has been designed to take either an inventory and impact point of view, thus providing indicators for the online monitoring of the company operations, or assessing their impacts in an LCA-LCC perspective. In selecting the indicators and the definition of the framework structure, five industrial cases covering different business sectors were involved in identifying the most critical indicators in terms of calculability and defining a structure that would allow for their application in various business situations. Therefore, the defined framework has been validated at a conceptual level, thus laying the basis for future quantitative validation. Twenty key performance indicators (KPIs) for assessing the sustainability of manufacturing firms have been created based on the 163 indicators studied.
\end{abstract}

Keywords: sustainability; sustainability manufacturing; life cycle inventory; life cycle impact assessment (LCIA) methods

\section{Introduction}

To support the reading of the paper, Table 1 provides all the acronyms used in the present study.

Protecting our planet is quickly becoming a priority for everyone. Consumers look to sustainable brands, and brands look to more sustainable manufacturers who can boost their value and offering. In the last few decades, the sustainability of manufacturing has been the focus of discussions due to its important role in value creation in national economies and its sustainability impact [1]. "Sustainability" is not just a feel-good term or a process that helps businesses to move ahead of the pack. By adopting sustainable practices, a company 
can effectively conserve the earth's natural and non-renewable resources, improving its economic, environmental, and social performance [2].

Table 1. A list of abbreviations used in the text.

\begin{tabular}{|c|c|}
\hline Abbreviation & Definition \\
\hline CAPEX & Capital Expenditure \\
\hline CBS & Cost Breakdown Structure \\
\hline DSS & Decision Support System \\
\hline EPA & US Environmental Protection Agency \\
\hline EPD & Environmental Product Declaration \\
\hline EPIs & Energy Performance Indicators \\
\hline GHG & Greenhouse Gases \\
\hline GRI & Global Reporting Initiative \\
\hline IoT & Internet of Things \\
\hline KPI & Key Performance Indicators \\
\hline LCA & Life Cycle Assessment \\
\hline LCC & Life Cycle Costing \\
\hline LCCA & Life Cycle Cost Assessment \\
\hline LCEA & Life Cycle Energy Assessment \\
\hline LCI & Life Cycle Inventory \\
\hline LCIA & Life Cycle Impact Assessment \\
\hline NIST & National Institute of Standards and Technology \\
\hline NPV & Net Present Value \\
\hline $\mathrm{O} \& \mathrm{M}$ & Operation and Maintenance \\
\hline OECD & Organization for Economic Cooperation and Development \\
\hline OEF & Organization Environmental Footprint \\
\hline OPEX & Operational Expense \\
\hline PCRs & Product Category Rules \\
\hline PEF & Product Environmental Footprint \\
\hline ProdSI & Product Sustainability Index \\
\hline $\mathrm{REACH}$ & Registration, Evaluation, Authorization and Restriction of Chemicals \\
\hline SMEs & Small Medium Enterprises \\
\hline SMIR & Sustainable Manufacturing Indicator Repository \\
\hline SoA & State of the Art \\
\hline TBL & Triple Bottom Line \\
\hline
\end{tabular}

The concept of sustainable manufacturing has emerged over the past 40 years; the most common definition is proposed by the U.S. Environmental Protection Agency (EPA), defining sustainable manufacturing as "creation of manufactured products through economicallysound processes that minimize negative environmental impacts while conserving energy and natural resources. Sustainable manufacturing also enhances employee, community and product safety." [3]. The general principle is to reduce the intensity of material use, energy consumption, emissions, and the creation of unwanted by-products while improving the value of products to organizations and to society [4]. However, many organizations try to opt for this strategy, but due to price competition, they tend to focus on quality issues, lacking the integration of the enablers of sustainable manufacturing to overcome barriers [5]. This makes it difficult for organizations to successfully and strategically implement sustainable manufacturing [6]. A recent study carried out by Yadav et al. [7] defines the 
internet of things (IoT), big data analytics, blockchain technology, machine learning, etc., as enabling technologies.

It has thus become vital for manufacturers to find effective measurement methods to assess sustainability. To do so, appropriate performance measures supported with suitable indicators need to be developed to assess the impacts of manufacturing organizations. Also, structured frameworks using these measures can be very useful tools for practitioners to assess the sustainability of their business models. Particularly in the US and the EU, there has been increased interest from both industry and governmental bodies for pursuits in sustainable manufacturing [8]. In this context, the Organization for Economic Cooperation and Development (OECD) developed a toolkit that provides 18 [9] of the most important and commonly applicable indicators for environmental performance that will help evaluate and drive sustainability at facilities. The National Institute of Standards and Technology (NIST) developed the Sustainable Manufacturing Indicator Repository (SMIR) [10], which is a set of centralized, open indicators that, covering the three dimensions of sustainability, can be accessible by small and medium-size enterprises [11]. In 2011, the DG Environment and the European Commission's Joint Research Centre developed a common methodology for the calculation of product and organization environmental impacts. These methods are called Product Environmental Footprint (PEF) and Organization Environmental Footprint (OEF) and allows for the measurement and communication of life cycle performance [12].

It is, therefore, possible to state that sustainability has been a growing priority for businesses worldwide. Recently, energy efficiency has garnered significant attention from academics and industry due to the environmental and economic costs connected with energy consumption and the new global policies and goals, such as Europe's 2030 strategy. In fact, $24.2 \%$ of global GHG impacts (12 Gt of eq. $\mathrm{CO}_{2}$ emissions) are generated by the use of energy in industry [13,14].

In this context, there are a variety of examples concerning the integration of sustainability concepts in the manufacturing processes. Peruzzini and Pellicciari [15] introduced a list of environmental KPIs for the design stage, focusing on many aspects related to the sustainability concept, but in the conceptualization phase. Brundage [16] established new indices to analyze energy structure in the production line. Amrina and Yusof [17] emphasize the need to evaluate sustainability through a set of specific key performance indicators. May [18] analyzed the current state of the art on energy related production performance indicators and derived research gaps related to the industrial needs for equipment evaluation. Sustainability has been integrated into manufacturing management areas such as product development [19], supply chain management [20,21], lean manufacturing [22], and supplier evaluation and selection [23].

Even if the literature review shows a growing interest regarding sustainable manufacturing benefits (i.e., impacts limitation, cost reduction, and broad recognition), very few studies integrate the assessment of sustainability performance at the process and corporate level. Even fewer studies exist dealing with structured industrial sustainability frameworks where metrics are defined based on a hierarchical structure, thus providing the basis for the development of decision support systems (DSS).

Considering the concept of industry ecology [24], the purpose of this research is therefore to integrate sustainability practices into manufacturing processes by providing a set of key performance indicators (KPIs) for evaluating and improving environmental and economic management practices at the corporate and production levels. To enhance the applicability and the understanding of the indicators, economic KPIs have been further divided into cost, CAPEX, and OPEX, based on life cycle costing (LCC) rationales, while environmental indicators have been divided into inventory and impact indicators, based on the life cycle assessment (LCA) approach. As sustainable manufacturing is pursued only if the economic and environmental perspectives are achieved together, the indicators addressing the economic performance of the considered systems are also integrated.

Ultimately, this study aims to provide manufacturing companies with a sustainability framework where the KPIs are validated with industrial cases in terms of applicability, 
calculous, and relevance. Furthermore, the alternative method developed to assess and select the indicators to be used, shared from the outset with the industrial cases, aims to ensure the terms described above. Finally, the selected industrial cases cover the mechanical manufacturing process, which is characterized as typical discrete manufacturing having a wide distribution in operations with a large consumption of energy and low efficiency. In addition, the framework laid the foundation for the development of a decision support system through the structure of indicators defined in Section 3.3.

\section{Materials and Methods}

The growing introduction of sustainability enablers for manufacturing, such as Industry 4.0 software, IoT, and big data analytics in the industrial domain is paving the way for structuring data rich environments, in addition to energy modeling approaches that exploit continuous data collection for automated model learning can be defined. Currently, optimizing energy consumption and the use of resources in manufacturing processes to achieve significant impact limitations and cost reduction is the aim of all manufacturing companies.

Framing our research in this context, in the following section, we focused on the analysis of the indicators and frameworks which follow the three main drivers of our research: being easily exploitable at the company level, having a focus on processes more than on products, and showing a special emphasis on energy consumption. The analysis started with a general overview of methods and frameworks related to the assessment of environmental and economic impacts, next focusing on inventory and impact level indicators.

\subsection{State of the Art Analysis}

In recent years, several frameworks have been proposed to assess sustainable manufacturing, which has been recognized as a driver for gaining a competitive advantage. In this context, the implementation of key performance indicators (KPIs) within the triple bottom line of sustainability, is a critical need to achieve higher market share, better product quality, and improved profits [25].

This section presents some of the most prominent works with respect to the integration of the LCA methodology, which is one the most mature and standardized approaches for the evaluation of environmental burdens [26]. Considering the entire life cycle of a product (or process), the LCA approach quantifies inputs and outputs, converting them into environmental and health impacts associated with any good or service. To improve understanding, the analysis is divided between inventory and impact indicators. Even though inventory indicators can be useful measures for reporting, monitoring, and supporting decision making, they do not provide any information about the impact on the environment. Especially at the industrial level, this dual vision is becoming increasingly important in order to provide stakeholders with a clear vision of resource management and, contrastingly, with a view of the potential impact of the company's activities on the environment. LCA is based of four main steps. The first phase, the goal and scope phase, sets the study's objective, including the intended application and audience. The system boundaries, the functional unit, and the allocation procedures are also defined in this stage. The second phase is the life cycle inventory (LCI) and involves the quantification of the inputs and outputs of the system. When performing the LCI, there are two types of data: foreground data, which are very specific to the model of the system, and background data, which can be found on publicly available databases. The third phase is the life cycle impact assessment (LCIA) and concerns the conversion of LCI data into impacts through the use of characterization models. Finally, the LCIA results are interpreted according to the declared purpose and scope of the study.

If LCA is focused on the area of environmental sustainability, life cycle cost analysis (LCCA), and in other words, life cycle costing (LCC), is a process to determine the sum of all expenses associated with a product, process, subprocess, or project, including acquisition and all associated costs, operation and maintenance (O\&M), refurbishment, and retirement costs [27-29]. The LCCA process consists of several steps. The first step of LCCA is to define 
the scope and the baseline. The "scope" means aspects such as whole cost, cost savings, and benefits count, what is the scope of the activities to be modeled, and the identity of the main stakeholders, etc. The second step focuses on the identification of cost categories. To estimate the life cycle cost, it is necessary to first divide the costs into applicable costs categories. The third step is data collection. A detailed data collection process must be defined. The main issue in data collection is to ensure the quality of the data that will be used in the calculations. In the fourth step, the valuation phase, monetary values should be given to costs and cost savings. Often, engineering and manufacturing estimates for costs and related profits are available (market prices). Older estimates available may be updated to the present value of appropriate factors, such as annual discounting and escalation factors. In addition, it should be considered that comparing cash flows from different periods can be achieved only by incorporating the time value of money (discounting). Although discounting is a generally accepted practice, the applied discount rate is often controversial. In business circles, high discount rates are applied so that current financial flows have a higher weight. In contrast, from a societal or environmental point of view, low discount rates are preferred to avoid the fact that current activities impose large costs on future generations [30].

\subsubsection{Inventory Indicators}

As a consequence of continuing climate change, increasing natural resource depletion, and environmental pollution, improving process sustainability has become a global trend. Following the growing interest in sustainable production and consumption fostered by modern society, scholars and practitioners have recently become active in the development of assessment frameworks to support companies in achieving more sustainable processes. The following section provides a review of sustainability frameworks strictly related to inventory indicators, without considering the impact on the environment.

Chofreh et al. [31] provided a summary of the best-known indicators sets highlighting the gaps and inconsistencies of the most accepted frameworks. They revealed two fundamental paradigms that must be considered when developing a sustainability framework. These are the sustainability paradigm (environmental, economic, and social) and the decisional paradigm (tactical, operational, and strategic). While the first paradigm has already been discussed and concerns the three areas of sustainability (environmental, economic, and social), for the decisional paradigm, the authors identified three levels. The first is the strategic level, which refers to the activities and tasks of top management. The second is the tactical level, which pertains to activities and tasks of mid-level management. The third dimension is the operational level, which concerns the activity and tasks of the supervisory level. The results showed that the majority of the framework considered the sustainability paradigm, but lacked integration with the decisional paradigm, which is critical for a successful sustainability implementation project.

When building a sustainability framework, it is important to provide indicators that assess the amount of particles in the air, soil, and water coming from the industrial processes. In fact, these indicators are essential because they heavily contribute to environmental impacts such as acid rain, the greenhouse effect, and ozone depletion. Another important aspect of environmental sustainability concerns the optimization of materials usage. Generally measured in a percentage or volume over a normalization factor, these indicators help companies to monitor and assess materials usage in terms of efficiency, recyclability, and reuse. Reducing natural resource consumption and improving the efforts to address "green-ness" is becoming a key factor for manufacturing companies to achieve competitive advantages.

In this sense, Winroth et al. [32] proposed a sustainability framework applicable at the factory level, aimed at measuring progress as well as being comparable between factories. According to the three areas of sustainability, the authors presented a framework comprised of a list of indicators broken down into the different aspects of sustainability. The set of indicators has also been proved to be easy and intuitive to use, since the KPIs has been 
selected according to their relevance and their applicability to the manufacturing sector. However, the research does not address assessment or include a comprehensive evaluation to cover all the required aspects described. A more structured framework has been provided by Huang and Badurdeen [33]. Based on a study related to the implementation of a product sustainability index (ProdSI) [34], the authors developed a framework for the enterprise level following a five-stage metric hierarchy (individual metrics, sub-clusters, clusters, sub-index, and index). The framework builds upon three fundamental pillars which are defined as the triple bottom line (economic, environmental, and social impact), the $6 \mathrm{R}$ methodology (reduce, reuse, remanufacture, recycle, redesign, recover), and total life cycle concept focusing on the entire life cycle of a product or service, from pre-manufacturing to post-use.

Despite the fact that these frameworks has been proved to be intuitive and applicable in the manufacturing sector, they consider the factory as a whole, a do not allow for a sustainability assessment at the production level. To overcome this gap, Tan et al. [35] reviewed four existing frameworks, selecting the indicators that could potentially facilitate SMEs to improve their sustainability performance. Starting from 405 indicators and following a top-down approach, the authors developed a selection methodology so that the chosen indicators should be understandable by non-experts, applicable to the manufacturing industry at the production level, and relevant to sustainability improvement. The initial 405 indicators were then skimmed, resulting in a list of 40 KPIs which can be considered as a repository of indicators for SMEs, but which are not meant to be integrated into business strategies. Further analysis presented by Donnelly et al. [36] highlighted the implementation of 18 common KPIs that support internal management and the decisionmaking process. More recent analyses presented by Hristov and Chirico [37] have been carried out with the aim of, first, identifying suitable KPIs that affect company performance and second, proposing sustainability practices to incorporate into company strategies. Starting from a literature review, the authors identified, for each area of sustainability, four cluster to which the KPIs were assigned. Additionally, following a survey conducted with Italian managers, they select the most appropriate indicators providing a way to integrate sustainability issues into the companies' strategies.

As shown above, the literature shows an abundance of sustainability frameworks that include an increasing number of KPIs, but lack in real usefulness for manufacturing enterprises. Park and Kremer [38] discussed the absence of a commonly accepted categorization framework. This issue has been addressed following a bottom-up approach, allowing for a categorization based on industrial perceptions and their text-based objective information, investigating the industrial perception on indicator use. Starting from 55 indicators extracted from the literature, the authors developed a survey to reveal the perception of utilization status (i.e., used in practice or future implementation) and utility (i.e., usefulness and practicality). A list of companies has been then identified to be surveyed and as result, each indicator has been classified based on its use in practice, usefulness, and practicalities, from an industrial perspective.

The documents presented thus far are mainly related to the environmental area, without focusing as much the economic and social aspects. Mostly targeting the economic area, Fan et al. [39] investigate the applicability of manufacturing sustainability indicators in the industrial environment. With the aim of raising awareness, supporting the decisionmaking processes, and measuring progress, the authors present a list of indicators according to the TBL of sustainability. Then, each indicator is then assessed by a number of industries in terms of relevance, analytical soundness, and measurability. As a result, a ranking of the metrics within each dimension of sustainability is provided.

Sustainability is a growing concern and many methodologies have been developed to assess and support companies' strategies for conforming to the TBL of sustainability. However, the literature indicates that the available frameworks show some limitations: (a) they are only appropriate for the company as a whole; (b) they are too complicated to be used as a practical tool; (c) they consider the environmental, social, and economic aspects 
separately with no integration between them. In this context, Lucato et al. [40] proposed a framework integrating sustainability variables into a single, combined measure. Going beyond the TBL concept, Joung et al. [41] review a set of publicly available indicator sets allowing for the categorization of quantifiable indicators related to manufacturing. So, with the final aim of providing a repository for manufacturing companies, the authors present a categorization of sustainable indicators considering the following five dimensions of sustainability: environmental stewardship, economic growth, social well-being, technological advancement, and performance management.

Most of the frameworks presented lack an effective method of reporting sustainability measures. In this sense, Tarquinio et al. [42] provide a review of GRI indicators in corporate sustainability reports, also highlighting how the standard can help companies to communicate information about their environmental, economic, and social impact in a standardized way. This allows organizations to be transparent, enhancing global comparability with the aim of raising the awareness of sustainability issues. GRI standards [43] are indeed designed as modular sets divided into two main topics, the universal standards (GRI 100) and the specific standards, such as economic (GRI 200), environmental (GRI 300), and social aspects (GRI 400). Lastly, the authors demonstrate the use of GRI 300 indicators to support environmental sustainability, selecting the KPIs coming from the following five blocks: GRI 301: materials [44], GRI 302: energy [45], GRI 303: water and effluents [46], GRI 305: emissions [47], and GRI 306: waste [48].

In terms of energy assessments, these methods can provide an effective way to implement solutions to reduce costs and diminish environmental emissions within manufacturing facilities [49]. Industrial manufacturing is the largest end-use sector, accounting for more than $30 \%$ of final energy demand [50]. The need to reduce energy-related environmental impacts makes the energy management processes a key factor for sustainable production [51]. The literature points out an abundance of energy performance indicators (EPIs), but only some of them are fully applicable in a manufacturing context. These indicators can be particularly useful for monitoring performance, analyzing consumption trends, and creating a solid baseline for comparative analysis between similar companies. As part of the LCEA (life cycle energy assessment) study, Arvidsson and Svanström [52] propose a set of five indicators for the overall assessment of energy consumption, enabling best practices, but also identifying potential barriers and drivers in the utilization of energy KPIs. In the context of this study, further analysis carried out by Mayer et al. [53] shows that losses at production level are not even considered.

In the context of energy savings, Coroiu and Chindris [54] and Li-Ming Wu and Chen [55] discuss the importance of using specific indicators to measure the energy that could be saved if the performance of the reference system were at best-practice level. The authors also clarify issues related to the time span over which the indicators should be scaled. In general, the literature does not show a large number of indicators in the area of energy efficiency; this is likely due to the fact that currently popular EPIs are highly standardized and recognized, so no more are needed. Since the concept of energy efficiency depends on the scope of the application, S. Thiede [56] and Mayer et al. [53] provide their own definition and suggest a standardized method for the calculation of energy efficiency at the production level.

In order to provide a complete overview of the literature reviewed, the sustainability frameworks have been mapped against the sustainability paradigms discussed above. Also, a column highlighting the validation and relevance of the indicators used to the specific industry has also been added. Table 2 shows that most of the sustainability frameworks developed have a strong theoretical matrix, but lack industrial validation. In fact, the selected indicators are often difficult to integrate in a manufacturing environment in terms of computational applicability and relevance [35]. 
Table 2. Analysis of existing sustainability implementation frameworks based on literature review.

\begin{tabular}{|c|c|c|c|c|c|c|c|c|}
\hline \multirow{3}{*}{ Author (Year) } & \multicolumn{4}{|c|}{ Sustainability Dimensions } & \multicolumn{3}{|c|}{ Decision-Making Levels } & \multirow{3}{*}{$\begin{array}{l}\text { Industrial } \\
\text { Relevance } \\
\text { Validation }\end{array}$} \\
\hline & \multicolumn{2}{|c|}{ Environmental } & \multirow{2}{*}{ Social } & \multirow{2}{*}{ Economic } & \multirow{2}{*}{ Strategic } & \multirow{2}{*}{ Tactical } & \multirow{2}{*}{ Operational } & \\
\hline & Process & Corporate & & & & & & \\
\hline Hahn et al. (2015) & $\checkmark$ & & $\checkmark$ & $\checkmark$ & $\checkmark$ & $\checkmark$ & $\checkmark$ & \\
\hline Laurenti et al. (2016) & $\checkmark$ & $\checkmark$ & $\checkmark$ & $\checkmark$ & $\checkmark$ & & & \\
\hline Panagiotakopoulos et al. (2016) & & $\checkmark$ & $\checkmark$ & $\checkmark$ & $\checkmark$ & $\checkmark$ & $\checkmark$ & \\
\hline Gallotta et al. (2016) & & $\checkmark$ & $\checkmark$ & $\checkmark$ & $\checkmark$ & & & \\
\hline Winroth et al. (2012) [32] & $\checkmark$ & & $\checkmark$ & $\checkmark$ & $\checkmark$ & & $\checkmark$ & $\checkmark$ \\
\hline Huang and Badurdeen (2017) [33] & $\checkmark$ & $\checkmark$ & $\checkmark$ & $\checkmark$ & $\checkmark$ & $\checkmark$ & $\checkmark$ & \\
\hline Tan et al. (2015) [35] & $\checkmark$ & & $\checkmark$ & $\checkmark$ & $\checkmark$ & & $\checkmark$ & $\checkmark$ \\
\hline Donnelly et al. (2007) [36] & & $\checkmark$ & & & $\checkmark$ & & & \\
\hline Hristov and Chirico (2019) [37] & & $\checkmark$ & $\checkmark$ & $\checkmark$ & $\checkmark$ & $\checkmark$ & & \\
\hline Park and Kremer (2017) [38] & $\checkmark$ & $\checkmark$ & & $\checkmark$ & & & & \\
\hline Fan et al. (2010) [39] & $\checkmark$ & $\checkmark$ & $\checkmark$ & $\checkmark$ & $\checkmark$ & $\checkmark$ & $\checkmark$ & \\
\hline Lucato et al. (2018) [40] & $\checkmark$ & & $\checkmark$ & $\checkmark$ & $\checkmark$ & & $\checkmark$ & $\checkmark$ \\
\hline Joung et al. (2011) [41] & $\checkmark$ & $\checkmark$ & $\checkmark$ & $\checkmark$ & $\checkmark$ & $\checkmark$ & $\checkmark$ & \\
\hline Arvidsson and Svanström (2016) [52] & & $\checkmark$ & & & $\checkmark$ & & $\checkmark$ & \\
\hline Mayer et al. (2020) [53] & & $\checkmark$ & & & $\checkmark$ & & $\checkmark$ & \\
\hline Coroiu and Chindris (2014) [54] & & $\checkmark$ & & & $\checkmark$ & & & \\
\hline Li-Ming Wu and Chen (2007) [55] & $\checkmark$ & & & & & & $\checkmark$ & \\
\hline
\end{tabular}

\subsubsection{Impact Indicators}

As previously mentioned, inventory indicators do not provide any information about the impacts on the environment. For this reason, during the life cycle impact assessment (LCIA) phase, inventory data are converted into potential impacts on the environment through the characterization models. In order to provide companies with a harmonized and common methodology to measure and calculate the life cycle impacts of products and organizations, the European Commission developed two methods, called the Product Environmental Footprint (PEF) and the Organization Environmental Footprint (OEF) [57-59]. The two methods are closely related and share many elements. In fact, even though the PEF methodology is specific to individual products and the OEF considers the organization as a whole, both assessment methods apply to the same set of impact KPIs. Table 3 provides the list of 16 impact indicators extracted using the PEF and OEF methodologies.

Another important scheme is the environmental product declaration (EPD) [60] which is defined by ISO 14025 [61] as a Type III declaration that "quantifies LCA results enabling comparison between products or services fulfilling the same function". Companies develop EPDs with the aim of improving their sustainability goals, as well as demonstrating to their customers their commitment to the environment. Following the LCA methodology, EPDs studies may vary in terms of assumptions and general information; therefore, results of studies on products or services that fulfil the same function may not be comparable with one another.

For this reason, the product category rules (PCRs) [62] have been implemented with the aim of providing guidance for enabling the fair comparison between products belonging to the same product category. PCRs are provided in the form of documents indicating rules, requirements, and guidelines for the development of an EPD for a specific product category. 
Recently, the international EPD system published a list of environmental impact categories (Table 4) and the assessment methods to be used in EPDs. This list is updated on a regular basis and consists of a selection of the most important impact categories first developed using the OEF and PEF methodologies.

Table 3. PEF and OEF environmental indicators.

\begin{tabular}{|c|c|c|c|}
\hline Impact Category & Impact Category Indicator & Unit & Characterization Model \\
\hline Climate change, total & $\begin{array}{l}\text { Radiative forcing as global warming } \\
\text { potential (GWP100) }\end{array}$ & $\mathrm{kg} \mathrm{CO} 2$ eq. & $\begin{array}{l}\text { Baseline model of } 100 \text { years of the IPCC } \\
\text { (based on IPCC 2013) }\end{array}$ \\
\hline Ozone depletion & Depletion & kg CFC-11 eq. & $\begin{array}{l}\text { Steady-state ODPs as in (WMO } 2014+ \\
\text { integrations) }\end{array}$ \\
\hline Human toxicity, cancer & $\begin{array}{l}\text { Comparative Toxic Unit for humans } \\
\text { (CTUh) }\end{array}$ & CTUh & USEtox model 2.1 (Fankte et al., 2017) \\
\hline Human toxicity, non-cancer & $\begin{array}{l}\text { Comparative Toxic Unit for humans } \\
\text { (CTUh) }\end{array}$ & CTUh & USEtox model 2.1 (Fankte et al., 2017) \\
\hline Particulate matter & Impact on human health & Disease incidence & $\begin{array}{l}\text { PM method recommended by UNEP } \\
\text { (UNEP 2016) }\end{array}$ \\
\hline $\begin{array}{l}\text { Ionizing radiation, human } \\
\text { health }\end{array}$ & $\begin{array}{c}\text { Human exposure efficiency relative } \\
\text { to U235 }\end{array}$ & kBq U235 eq. & $\begin{array}{c}\text { Human health effect model as developed } \\
\text { by Dreicer et al. } 1995 \text { (Frischknecht et al., } \\
\text { 2000) }\end{array}$ \\
\hline $\begin{array}{l}\text { Photochemical ozone formation, } \\
\text { human health }\end{array}$ & $\begin{array}{l}\text { Tropospheric ozone concentration } \\
\text { increase }\end{array}$ & kg NMVOC eq. & $\begin{array}{l}\text { LOTOS-EUROS model (Van Zelm et al., } \\
\text { 2008) as implemented in ReCiPe } 2008\end{array}$ \\
\hline Acidification & Accumulated Exceedance (AE) & $\mathrm{mol} \mathrm{H}+$ eq. & $\begin{array}{c}\text { Accumulated Exceedance (Seppälä et al., } \\
\text { 2006, Posch et al., 2008) }\end{array}$ \\
\hline Eutrophication, terrestrial & Accumulated Exceedance (AE) & mol $\mathrm{N}$ eq. & $\begin{array}{l}\text { Accumulated Exceedance (Seppälä et al., } \\
\text { 2006, Posch et al., 2008) }\end{array}$ \\
\hline Eutrophication, freshwater & $\begin{array}{l}\text { Fraction of nutrients reaching } \\
\text { freshwater end compartment }(\mathrm{P})\end{array}$ & kg P eq. & $\begin{array}{l}\text { EUTREND model (Struijs et al., 2009) as } \\
\text { implemented in ReCiPe }\end{array}$ \\
\hline Eutrophication, marine & $\begin{array}{l}\text { Fraction of nutrients reaching } \\
\text { marine end compartment }(\mathrm{N})\end{array}$ & $\mathrm{kg} \mathrm{N}$ eq. & $\begin{array}{l}\text { EUTREND model (Struijs et al., 2009) as } \\
\text { implemented in ReCiPe }\end{array}$ \\
\hline Ecotoxicity, freshwater & $\begin{array}{l}\text { Comparative Toxic Unit for } \\
\text { ecosystems (CTUe) }\end{array}$ & CTUe & USEtox model 2.1 (Fankte et al., 2017) \\
\hline Land use & $\begin{array}{c}\text { Soil quality index } \\
\text { Biotic production } \\
\text { Erosion resistance } \\
\text { Mechanical filtration } \\
\text { Groundwater replenishment }\end{array}$ & $\begin{array}{c}\text { Dimensionless }(\mathrm{pt}) \\
\mathrm{kg} \text { biotic production } \\
\mathrm{kg} \text { soil } \\
\mathrm{m}^{3} \text { water } \\
\mathrm{m}^{3} \text { groundwater }\end{array}$ & $\begin{array}{l}\text { Soil quality index based on LANCA (Beck } \\
\text { et al., } 2010 \text { and Bos et al., 2016) }\end{array}$ \\
\hline Water use & $\begin{array}{l}\text { User deprivation potential } \\
\text { (deprivation-weighted water } \\
\text { consumption) }\end{array}$ & $\mathrm{m}^{3} \mathrm{H}_{2} \mathrm{O}$ eq. & $\begin{array}{l}\text { Available Water Remaining (AWARE) as } \\
\text { recommended by UNEP, } 2016\end{array}$ \\
\hline $\begin{array}{l}\text { Resource use, minerals and } \\
\text { metals }\end{array}$ & $\begin{array}{c}\text { Abiotic resource depletion (ADP } \\
\text { ultimate reserves) }\end{array}$ & $\mathrm{kg} \mathrm{Sb}$ eq. & $\begin{array}{l}\text { CML } 2002 \text { (Guinée et al., 2002) and van } \\
\text { Oers et al., 2002. }\end{array}$ \\
\hline Resource use, fossils & $\begin{array}{l}\text { Abiotic resource depletion-fossil } \\
\text { fuels (ADP-fossil) }\end{array}$ & MJ & $\begin{array}{c}\text { CML } 2002 \text { (Guinée et al., 2002) and van } \\
\text { Oers et al., 2002 }\end{array}$ \\
\hline
\end{tabular}


Table 4. EPD environmental indicators.

\begin{tabular}{|c|c|c|c|}
\hline Impact Category & Impact Category Indicator & Unit & Characterization Model \\
\hline Climate change, total & Global Warming Potential & $\mathrm{kg} \mathrm{CO}_{2}$ eq. & GWP100, CML 2001 baseline \\
\hline $\begin{array}{l}\text { Photochemical ozone formation, } \\
\text { human health }\end{array}$ & $\begin{array}{l}\text { Photochemical oxidant formation } \\
\text { potential }\end{array}$ & kg NMVOC eq. & $\begin{array}{l}\text { POFP, LOTOS-EUROS as applied in } \\
\text { ReCiPe, } 2008\end{array}$ \\
\hline Acidification & Accumulated potential & $\mathrm{kg} \mathrm{SO}_{2}$ eq. & $\begin{array}{c}\text { AP, CML } 2001 \text { non-baseline (fate not } \\
\text { included) }\end{array}$ \\
\hline Eutrophication, freshwater & Eutrophication potential & kg PO43-eq. & EP, CML 2001 baseline \\
\hline Water use & Water Scarcity Footprint (WSF) & $\mathrm{m}^{3} \mathrm{H}_{2} \mathrm{O}$ eq. & $\begin{array}{l}\text { AWARE Method: WULCA } \\
\text { recommendations on characterization } \\
\text { model for WSF 2015, } 2017\end{array}$ \\
\hline Resource use, minerals and metals & Abiotic depletion potential—elements & $\mathrm{kg} \mathrm{Sb}$ eq. & ADP elements, CML 2001 baseline \\
\hline Resource use, fossils & $\begin{array}{l}\text { Abiotic depletion potential—fossil } \\
\text { fuels }\end{array}$ & MJ & ADP fossil fuels, CML 2001 baseline \\
\hline
\end{tabular}

\subsubsection{Economic Indicators}

In the manufacturing sector, there is a strong need to create indicators that can support decision making and control the performance of enterprises. According to Linke [63], indicators rarely have the same relevance for the user and the company. Companies may also place greater weight on economic aspects rather than environmental and social sustainability. A survey-based statistical analysis by Amrina and Lutfia Vilsi [64] highlights how economic sustainability is the most important among the triple bottom line factors (social, environmental, and economical). They also identify the inventory cost indicator as the most important within the economic category. Similarly, Patil and Javalagi [65] confirm that economic sustainability is the most important aspect from the point of view of the companies. In this case, they identify profitability as the most important indicator within the economic category. Akbar and Irohara [66] provide an updated list of economic KPIs divided into financial performance, delivery reliability, and manufacturing cost. Kravchenko et al [67] discuss the most prevalent economic aspects in corporate reporting, providing a set of economic KPIs distributed according to business processes. The global reporting initiative (GRI) guidelines Winroth et al. [32] developed a set of economic indicators integrated at the factory level to communicate economic performance. In conclusion, the respect for the economic dimension is guaranteed by ISO 9001 and UNE 166002, which allow the quality of financial and economic performance to be certified. Company certification has a direct influence on its performance and management; this allows companies to improve their reputations and enhances relationships with stakeholders.

\subsection{Methodology for Framework Development}

As mentioned above, in the literature there are several works that endeavor to address the development of framework indicators to support companies in the understanding and improvement of their processes from an environmental and economic perspective, yet several shortcomings are still present. As reported in the literature, many indicators set, especially those at corporate level, are more oriented to offer an overall view without allowing for the vision on a single process. While this can support high-level analysis of company behavior, it is not helpful when short-term decisions and analysis must be considered. In this respect, we aim to fill this identified gap by defining a comprehensive framework integrating inventory and impact indicators meant to meet the industrial needs in terms of comprehensiveness of the analysis and usability of the developed set. The adopted methodology for addressing this challenge is described hereafter.

Following the SoA analysis at the framework and indicators level described above, a generic list of indicators integrating the two perspectives has been collected. The list is then filtered by applying the requisites indicated by the context of our work, and through 
the involvement of a group of industries in the assessment, scoping and selecting a subset of required indicators. This is done to maintain the closeness of the framework to the expected end users. The results of industrial involvement are exploited to design the final version of the list of indicators. Once the initial list has been polished, a work aiming at simplifying the access to the indicators has been produced. In particular, a clustering and causal nexus among the indicators has been created, restricting the number of key performance indicators, under which the full list of indicators is provided.

In the following diagram (Figure 1), the process of defining the framework is depicted and a high-level description is provided.

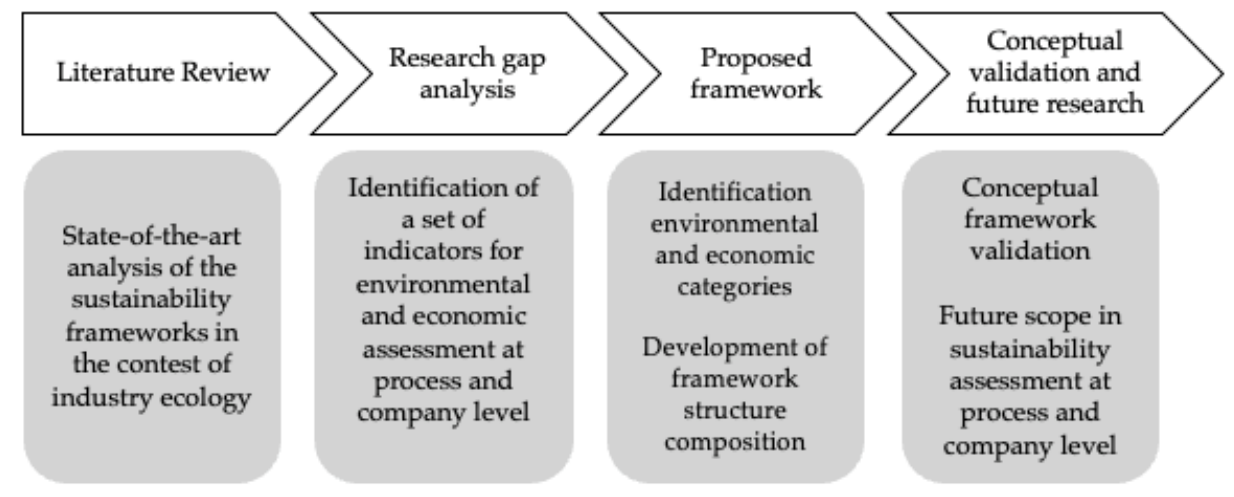

Figure 1. Research methodology used in the study.

\section{Design of the Framework of Indicators}

The selection methodology used to define the indicators' set is based on two main selection steps. In the first step, starting from the results obtained from the SoA analysis of the available indicators for the manufacturing sector, it was decided to consider environmental and economic sustainability aspects, without considering the social aspect, and add a section focusing on the attention on energy performance indicators. Afterwards, considering the market sectors covered by the companies and the objectives defined for the framework, a list of indicators was defined based on the interaction and analysis phase, with the industrial companies supporting the conceptual validation.

The industrial sectors covered by the five selected industrial cases faithfully represent the mechanical manufacturing process, with applications in the automotive, medical, and industrial machinery sectors. Moreover, the selected industrial cases are characterized by very different organizational structures, sizes, and applications, thus making the conceptual validation of the framework more effective.

The second stage of indicator selection and development was then based on the information obtained from the various activities carried out with the industries and aimed at creating independent clustering frameworks grouping the indicators using guiding categories to allow integration and usability. During the interaction phase with the industrial cases, in order to avoid problems related to the sensitivity of the data needed to assess environmental and economic impacts, it was agreed to define the boundaries of the system in such a way as to include only the processes within the company under review, and therefore, not to consider the entire supply chain.

Concerning impact indicators, the selection methodology differed from that explained above. In this specific case, the leading indicators available, provided by PEF, OEF, and EPD have been selected, and the most significant indicators have been chosen according to the needs of the framework.

The methodology implemented aims to develop a conceptual industry-oriented environmental and economic framework based on theoretical findings and practical feedback, which can be used for subsequent quantitative studies. 


\subsection{Definition of the Reference Indicators List}

In the literature review, the leading sustainable manufacturing indicators have been examined to create a solid base from which to select the most appropriate indicators for the framework. As a result, more than 160 sustainability indicators in the manufacturing sector were taken into account as a starting point.

In the following tables, the indicators examined in the literature review and used as a baseline are reported, divided into environmental and energy performance indicators (Table 5), social performance indicators (Table 6), impact indicators (Table 7), and economic performance and cost indicators (Table 8).

Table 5. Environmental and energy performance indicators extracted from the literature.

\begin{tabular}{|c|c|c|}
\hline $\mathrm{Nr}$ & Indicator & Source \\
\hline 1 & Total emissions & Amrina \& Vilsi, 2015 [64] \\
\hline 2 & Emissions of ozone depleting substances & Amrina \& Vilsi, 2015 [64] \\
\hline 3 & Emissions of GHG & Amrina \& Vilsi, 2015 [64] \\
\hline 4 & Sulphur dioxides $\left(\mathrm{SO}_{\mathrm{x}}\right.$ emissions) & Chengcheng Fan et al., 2010 [39] \\
\hline 5 & Nitrogen oxides ( $\mathrm{NO}_{x}$ emissions) & Chengcheng Fan et al., 2010 [39] \\
\hline 6 & Percentage of waste generated & Hristov and Chirico, 2019 [37] \\
\hline 7 & Percentage of hazardous material & Chengcheng Fan et al., 2010 [39] \\
\hline 8 & Percentage of reusable/recycled material & H. X. Tan et al., 2015 [35] \\
\hline 9 & Percentage of waste recycled off/on site & Hristov and Chirico, 2019 [37] \\
\hline 10 & Renewable material use & Fan et al., 2010 [39] \\
\hline 11 & Non-renewable material use & Fan et al., 2010 [39] \\
\hline 12 & Weight of restricted substances intensity & OECD Sustainable Manufacturing Indicators [9] \\
\hline 13 & Recycled/reused content of material inputs & OECD Sustainable Manufacturing Indicators [9] \\
\hline 14 & Energy intensity & Andersson and Thollander, 2019 [68]/GRI 302 \\
\hline 15 & Electricity consumption & OECD Sustainable Manufacturing Indicators [9] \\
\hline 16 & Gas consumption rate & OECD Sustainable Manufacturing Indicators [9] \\
\hline 17 & Natural cover & OECD Sustainable Manufacturing Indicators [9] \\
\hline 18 & Water intensity & OECD Sustainable Manufacturing Indicators [9] \\
\hline 19 & Waste intensity & OECD Sustainable Manufacturing Indicators [9] \\
\hline 20 & Emissions intensity & OECD Sustainable Manufacturing Indicators [9] \\
\hline 21 & Renewable energy rate & Winroth et al., 2012 [32] \\
\hline 22 & Renewable electric sources rate & Winroth et al., 2012. [32] \\
\hline 23 & Resource efficiency & Park and Kremer, 2017 [38] \\
\hline 24 & Specific energy consumption & Coroiu and Chindris, 2014 [54] \\
\hline 25 & Energy savings & Coroiu and Chindris, 2014 [54] \\
\hline 26 & Energy waste & Mayer et al., 2020 [53] \\
\hline
\end{tabular}


Table 5. Cont.

\begin{tabular}{|c|c|c|}
\hline $\mathrm{Nr}$ & Indicator & Source \\
\hline 27 & Net energy indicator & Mayer et al., 2020 [53] \\
\hline 28 & Cumulative energy demand & Arvidsson and Svanström, 2016 [52] \\
\hline 29 & Non-renewable energy demand & Arvidsson and Svanström, 2016 [52] \\
\hline 30 & Fossil energy use & Arvidsson and Svanström, 2016 [52] \\
\hline 31 & Primary fossil energy use & Arvidsson and Svanström, 2016 [52] \\
\hline 32 & Secondary energy use & Arvidsson and Svanström, 2016 [52] \\
\hline 33 & Energy saving potential & Coroiu and Chindris, 2014 [54] \\
\hline 34 & Total energy consumption & GRI 302: Energy 2016 [45] \\
\hline 35 & Energy efficiency & Sebastian Thiede, 2012 [56] \\
\hline 36 & Energy ratio & Mayer et al., 2020; [53] \\
\hline 37 & Output renewability & Mayer et al., 2020; [53] \\
\hline 38 & Total weight or volume of materials input & GRI $301[44]$ \\
\hline 39 & Total material input intensity & GRI 301 [44] \\
\hline 40 & Recycled input materials & GRI 301 [44] \\
\hline 41 & Total energy consumption & GRI 302 [45] \\
\hline 42 & Electricity consumption & GRI 302 [45] \\
\hline 43 & Heating consumption & GRI 302 [45] \\
\hline 44 & Cooling consumption & GRI 302 [45] \\
\hline 45 & Steam consumption & GRI 302 [45] \\
\hline 46 & $\begin{array}{l}\text { Percentage of renewable energy consumption generated by the } \\
\text { following sources: (i) hydroelectric, (ii) biomass, (iii) solar, (iv) } \\
\text { wind }\end{array}$ & GRI 302 [45] \\
\hline 47 & $\begin{array}{l}\text { Percentage of non-renewable energy consumption generated by } \\
\text { the following sources: (i) natural gas, (ii) coal, (iii) other fossil } \\
\text { fuels }\end{array}$ & GRI 302 [45] \\
\hline 48 & Reduction in energy consumption & GRI 302 [45] \\
\hline 49 & Total volume of water withdrawn & GRI 303 [46] \\
\hline 50 & $\begin{array}{l}\text { Percentage of water withdrawn from the following sources: (i) } \\
\text { surface water, (ii) ground, (iii) water, (iv)seawater, (v) } \\
\text { third-party water }\end{array}$ & GRI 303 [46] \\
\hline 51 & Total volume of water recycled and reused by the organization & GRI 303 [46] \\
\hline 52 & Total water discharge & GRI 303 [46] \\
\hline 53 & $\begin{array}{l}\text { Percentage of water discharge to the following sources: (i) } \\
\text { surface water, (ii) ground, (iii) water, (iv)seawater, (v) } \\
\text { third-party water }\end{array}$ & GRI 303 [46] \\
\hline 54 & $\begin{array}{c}\text { Percentage of fresh water ( } \leq 1000 \mathrm{mg} / \mathrm{L} \text { Total Dissolved Solids) } \\
\text { discharge for each destination }\end{array}$ & GRI 303 [46] \\
\hline
\end{tabular}


Table 5. Cont.

\begin{tabular}{|c|c|c|}
\hline $\mathrm{Nr}$ & Indicator & Source \\
\hline 55 & Acidifying substances & GRI 305 [47] \\
\hline 56 & Gases affecting climate change (GHG) & GRI 305 [47] \\
\hline 57 & Gases affecting ozone depletion (ODS) & GRI 305 [47] \\
\hline 58 & Persistent organic pollutants (POP) & GRI 305 [47] \\
\hline 59 & Volatile organic compounds (VOC) & GRI 305 [47] \\
\hline 60 & Hazardous air pollutants (HAP) & GRI 305 [47] \\
\hline 61 & Particulate matter (PM) & GRI 305 [47] \\
\hline 62 & Total weight of waste generated & GRI 306 [48] \\
\hline 63 & Percentage structure of waste generated (plastic, paper, metals) & GRI 306 [48] \\
\hline 64 & $\begin{array}{c}\text { Waste diverted from disposal } \\
\text { preparation for reuse, } \\
\text { recycling, } \\
\text { other recovery operations }\end{array}$ & GRI 306 [48] \\
\hline 65 & $\begin{array}{c}\text { Percentage of hazardous waste diverted from disposal (for each } \\
\text { category) }\end{array}$ & GRI 306 [48] \\
\hline 66 & $\begin{array}{l}\text { Percentage of non-hazardous waste diverted from disposal (for } \\
\text { each category) }\end{array}$ & GRI 306 [48] \\
\hline 67 & Percentage of hazardous waste reused & GRI 306 [48] \\
\hline 68 & Percentage of hazardous waste recycled & GRI 306 [48] \\
\hline 69 & Percentage of hazardous waste sent to other recovery operations & GRI 306 [48] \\
\hline 70 & Percentage of non-hazardous waste reused & GRI 306 [48] \\
\hline 71 & Percentage of non-hazardous waste recycled & GRI 306 [48] \\
\hline 72 & $\begin{array}{l}\text { Percentage of non-hazardous waste sent to other recovery } \\
\text { operations }\end{array}$ & GRI 306 [48] \\
\hline 73 & $\begin{array}{l}\text { Percentage of waste diverted form disposal recovered on/off } \\
\text { site (for each category) }\end{array}$ & GRI 306 [48] \\
\hline 74 & $\begin{array}{c}\text { Waste directed to disposal } \\
\text { Incineration (with energy recovery) } \\
\text { Incineration (without energy recovery) } \\
\text { Landfilling } \\
\text { Other disposal operations }\end{array}$ & GRI 306 [48] \\
\hline 75 & Percentage of non-hazardous waste directed to disposal & GRI 306 [48] \\
\hline 76 & Percentage of hazardous waste directed to disposal & GRI 306 [48] \\
\hline 77 & $\begin{array}{l}\text { Percentage of waste directed to landfilling, incinerator, or other } \\
\text { recovery operations }\end{array}$ & GRI 306 [48] \\
\hline 78 & Percentage of waste directed to other disposal operation & GRI 306 [48] \\
\hline 79 & Percentage of hazardous waste disposed on site & GRI 306 [48] \\
\hline 80 & Percentage of non-hazardous waste disposed on site & GRI 306 [48] \\
\hline
\end{tabular}


Table 6. Social performance indicators extracted from the literature.

\begin{tabular}{|c|c|c|}
\hline $\mathrm{Nr}$ & Indicator & Source \\
\hline 81 & Rate of employees that are shareholders & Hristov and Chirico, 2019 [37]. \\
\hline 82 & Employee satisfaction rate & Hristov and Chirico, 2019 [37]. \\
\hline 83 & Employee turnover rate & Hristov and Chirico, 2019 [37]. \\
\hline 84 & Accident rate & Hristov and Chirico, 2019 [37]. \\
\hline 85 & Time of employees working in dangerous workplaces & Hristov and Chirico, 2019 [37]. \\
\hline 86 & Noise level & Hristov and Chirico, 2019 [37]. \\
\hline 87 & Equality rate & Hristov and Chirico, 2019 [37]. \\
\hline 88 & Labor intensity & Hristov and Chirico, 2019 [37]. \\
\hline 89 & Percentage of participants in social initiatives & Hristov and Chirico, 2019 [37]. \\
\hline 90 & Absenteeism & Hristov and Chirico, 2019 [37]. \\
\hline 91 & Rate of employees that are shareholders & Winroth et al., 2012 [32] \\
\hline 92 & Employee satisfaction rate & Winroth et al., 2012 [32] \\
\hline 93 & Employee turnover rate & Dočekalová and Kocmanová, 2016 [69] \\
\hline 94 & Noise level in terms of decibel (db) & Akbar and Irohara, 2018 [66] \\
\hline 95 & Percentage of days of absence over the total number of working days & Akbar and Irohara, 2018 [66] \\
\hline 96 & Accident rate & Akbar and Irohara, 2018 [66] \\
\hline 97 & Time of employees working at risky workplace & Zarte et al., 2019 [70] \\
\hline 98 & Gender equality rate-balance of male to female ratio & Dočekalová and Kocmanová, 2016 [69] \\
\hline 99 & Labor intensity & Linke et al., 2013 [63] \\
\hline 100 & Number of initiatives at national and local level & Hristov and Chirico, 2019 [37]. \\
\hline 101 & $\begin{array}{c}\text { Total workforce by employment type, employment contract, and region, } \\
\text { broken down by gender }\end{array}$ & GRI 400: Social Disclosures \\
\hline 102 & $\begin{array}{c}\text { Total number and rate of new employee hires and employee turnover by age } \\
\text { group, gender, and region }\end{array}$ & GRI 400: Social Disclosures \\
\hline 103 & $\begin{array}{l}\text { Benefits provided to full-time employees that are not provided to temporary or } \\
\text { part-time employees, by significant locations of operation }\end{array}$ & GRI 400: Social Disclosures \\
\hline 104 & Return to work and retention rates after parental leave, by gender & GRI 400: Social Disclosures \\
\hline 105 & Percentage of employees covered by collective bargaining agreements & GRI 400: Social Disclosures \\
\hline 106 & $\begin{array}{l}\text { Minimum notice period(s) regarding operational changes, including whether it } \\
\text { is specified in collective agreements }\end{array}$ & GRI 400: Social Disclosures \\
\hline 107 & $\begin{array}{l}\text { Percentage of total workforce represented by informal joint } \\
\text { management-worker health and safety committees that help monitor and } \\
\text { advise on occupational health and safety programs }\end{array}$ & GRI 400: Social Disclosures \\
\hline 108 & $\begin{array}{c}\text { Rates of injury, occupational diseases, lost days, and absenteeism, and total } \\
\text { number of work-related fatalities, by region and by gender }\end{array}$ & GRI 400: Social Disclosures \\
\hline
\end{tabular}


Table 6. Cont.

\begin{tabular}{|c|c|c|}
\hline $\mathrm{Nr}$ & Indicator & Source \\
\hline 109 & $\begin{array}{l}\text { Education, training, counseling, prevention, and risk-control programs in } \\
\text { place to assist workforce members, their families, or community members } \\
\text { regarding serious diseases }\end{array}$ & GRI 400: Social Disclosures \\
\hline 110 & Health and safety topics covered in formal agreements with trade unions & GRI 400: Social Disclosures \\
\hline 111 & $\begin{array}{c}\text { Average hours of training per year per employee by gender, and by employee } \\
\text { category }\end{array}$ & GRI 400: Social Disclosures \\
\hline 112 & $\begin{array}{c}\text { Programs for skills management and lifelong learning that support the } \\
\text { continued employability of employees and assist them in managing career } \\
\text { endings }\end{array}$ & GRI 400: Social Disclosures \\
\hline 113 & $\begin{array}{c}\text { Percentage of employees receiving regular performance and career } \\
\text { development reviews, by gender }\end{array}$ & GRI 400: Social Disclosures \\
\hline 114 & $\begin{array}{l}\text { Composition of governance bodies and breakdown of employees per } \\
\text { employee category according to gender, age group, minority group } \\
\text { membership, and other indicators of diversity }\end{array}$ & GRI 400: Social Disclosures \\
\hline 115 & $\begin{array}{l}\text { Ratio of basic salary and remuneration of women to men by employee } \\
\text { category, by significant locations of operation }\end{array}$ & GRI 400: Social Disclosures \\
\hline
\end{tabular}

Table 7. Environmental impact indicators extracted from the literature.

\begin{tabular}{|c|c|c|}
\hline Nr. & Indicator & Source \\
\hline 116 & Radiative forcing as global warming potential (GWP100) & Baseline model of 100 years of the IPCC (based on IPCC 2013) \\
\hline 117 & Ozone Depletion Potential & Steady-state ODPs as in (WMO 2014 + integrations) \\
\hline 118 & Comparative Toxic Unit for humans (CTUh) & USEtox model 2.1 (Fankte et al., 2017) \\
\hline 119 & Comparative Toxic Unit for humans (CTUh) & USEtox model 2.1 (Fankte et al., 2017) \\
\hline 120 & Impact on human health & PM method recommended by UNEP (UNEP 2016) \\
\hline 121 & Human exposure efficiency relative to U235 & $\begin{array}{l}\text { Human health effect model as developed by Dreicer et al., } 1995 \\
\text { (Frischknecht et al., 2000) }\end{array}$ \\
\hline 122 & Tropospheric ozone concentration increase & $\begin{array}{l}\text { LOTOS-EUROS model (Van Zelm et al., 2008) as implemented in } \\
\text { ReCiPe 2008 }\end{array}$ \\
\hline 123 & Accumulated Exceedance (AE) & Accumulated Exceedance (Seppälä et al., 2006, Posch et al., 2008) \\
\hline 124 & Accumulated Exceedance (AE) & Accumulated Exceedance (Seppälä et al., 2006, Posch et al., 2008) \\
\hline 125 & Fraction of nutrients reaching freshwater end compartment $(\mathrm{P})$ & EUTREND model (Struijs et al., 2009) as implemented in ReCiPe \\
\hline 126 & Fraction of nutrients reaching marine end compartment $(\mathrm{N})$ & EUTREND model (Struijs et al., 2009) as implemented in ReCiPe \\
\hline 127 & Comparative Toxic Unit for ecosystems (CTUe) & USEtox model 2.1 (Fankte et al., 2017) \\
\hline 128 & $\begin{array}{c}\text { Soil quality index } \\
\text { Biotic production } \\
\text { Erosion resistance } \\
\text { Mechanical filtration } \\
\text { Groundwater replenishment }\end{array}$ & $\begin{array}{l}\text { Soil quality index based on LANCA (Beck et al., } 2010 \text { and Bos et al., } \\
\text { 2016) }\end{array}$ \\
\hline 129 & $\begin{array}{c}\text { User deprivation potential (deprivation-weighted water } \\
\text { consumption) }\end{array}$ & $\begin{array}{c}\text { Available Water Remaining (AWARE) as recommended by UNEP, } \\
2016\end{array}$ \\
\hline 130 & Abiotic resource depletion (ADP ultimate reserves) & CML 2002 (Guinée et al., 2002) and van Oers et al., 2002. \\
\hline 131 & Abiotic resource depletion-fossil fuels (ADP-fossil & CML 2002 (Guinée et al., 2002) and van Oers et al., 2002 \\
\hline 132 & Global Warming Potential & GWP100, CML 2001 baseline \\
\hline 133 & Photochemical oxidant formation potential & POFP, LOTOS-EUROS as applied in ReCiPe 2008 \\
\hline
\end{tabular}


Table 7. Cont.

\begin{tabular}{|c|c|c|}
\hline Nr. & Indicator & Source \\
\hline 134 & Accumulated potential & AP, CML 2001 non-baseline (fate not included) \\
\hline 135 & Eutrophication potential & EP, CML 2001 baseline \\
\hline 136 & Water Scarcity Footprint (WSF) & $\begin{array}{l}\text { AWARE Method: WULCA recommendations on characterization } \\
\text { model for WSF 2015, } 2017\end{array}$ \\
\hline 137 & Abiotic depletion potential-Elements & ADP elements, CML 2001, baseline \\
\hline 138 & Abiotic depletion potential-Fossil fuels & ADP fossil fuels, CML 2001, baseline \\
\hline
\end{tabular}

Table 8. Economic performance indicators extracted from the literature.

\begin{tabular}{|c|c|c|}
\hline Nr. & Indicator & Source \\
\hline 139 & Return of equity (ROE) & Kocmanova et al., 2017b [71]. \\
\hline 140 & Return on assets (ROA) & Kocmanova et al., 2017b [71]. \\
\hline 141 & Return on sale (ROS) & Kocmanova et al., 2017b [71]. \\
\hline 142 & Return on capital employed (ROCE) & Kocmanova et al., 2017b [71]. \\
\hline 143 & Return on Investment (ROI) & Kocmanova et al., 2017b [71]. \\
\hline 144 & Net Present Value (NPV) & Kocmanova et al., 2017b [71]. \\
\hline 145 & Present Value of Costs (PVC) & Kocmanova et al., 2017b [71]. \\
\hline 146 & Internal Rate of return IRR (\%) & Kocmanova et al., 2017b [71]. \\
\hline 147 & Pay Back Period (years) & Kocmanova et al., 2017b [71]. \\
\hline 148 & Discounted Pay Back Period (years) & Kocmanova et al., 2017b [71]. \\
\hline 149 & Total life cycle costs and cost savings (LCC) & Kocmanova et al., 2017b [71]. \\
\hline 150 & CAPEX & Kocmanova et al., 2017b [71]. \\
\hline 151 & OPEX (direct) & Kocmanova et al., 2017b [71]. \\
\hline 152 & OPEX (indirect) & Kocmanova et al., 2017b [71]. \\
\hline 153 & Lost revenue through production losses & Kocmanova et al., 2017b [71]. \\
\hline 154 & Productivity & Kocmanova et al., 2017b [71]. \\
\hline 155 & OEE (overall equipment effectiveness: availability, performance, quality) & Kocmanova et al., 2017b [71]. \\
\hline 156 & Delivery precision & Kocmanova et al., 2017b [71].; Winroth et al., 2012 [32] \\
\hline 157 & Percentage of money for the purchase from local suppliers & Kocmanova et al., 2017b [71]. \\
\hline 158 & Market demand and growth & Kocmanova et al., 2017b [71]. \\
\hline 159 & $\begin{array}{c}\text { Investments in environmental certification (ISO 9001, ISO 14001, ISO } \\
\text { 50001, UNE 166,002 and OHSAS 18001) }\end{array}$ & Kocmanova et al., 2017b [71]. \\
\hline 160 & Asset turnover & Dočekalová and Kocmanová, 2016 [69] \\
\hline 161 & Inventory turnover & Dočekalová and Kocmanová, 2016 [69] \\
\hline 162 & Net profit margin & Akbar and Irohara, $2018[66]$. \\
\hline 163 & Total cost of ownership & Hristov and Chirico, 2019 [37]. \\
\hline
\end{tabular}

\subsection{Indicator's List Filtering Based on Requirements}

Starting from the list presented above, a preliminary filtering step was conducted. It was decided not to consider indicators concerning the social aspect. Economic and cost indicators have not been subjected to this selection step. The indicators identified in the literature were used for the interaction and consultation activities with the businesses in order to directly define the final list of indicators to be used for the framework. Regarding environmental indicators, the first filtering step was based on the selection of the KPIs that 
potentially fulfil the following three criteria: measurability, industrial applicability, and comprehensibility by non-experts. The result of this step is shown in Table 9.

Table 9. KPIs list resulting from the first filtering step.

\begin{tabular}{|c|c|}
\hline Number & Indicator \\
\hline 3 & Emissions of GHG \\
\hline 2 & Emissions of ozone depleting substances \\
\hline 6 & Percentage of waste generated \\
\hline 7 & Percentage of hazardous materials \\
\hline 8 & Percentage of reusable/recycled materials \\
\hline 9 & Percentage of waste recycled off/on site \\
\hline 21 & Renewable energy rate \\
\hline 22 & Renewable electric sources rate \\
\hline 23 & Resource efficiency \\
\hline 11 & Non-renewable materials intensity \\
\hline 12 & weight of restricted substances intensity \\
\hline 18 & Water intensity \\
\hline 14 & Energy intensity \\
\hline 17 & Natural cover \\
\hline 28 & Cumulative energy demand \\
\hline 29 & non-renewable cumulative energy demand \\
\hline 30 & Fossil energy use \\
\hline 31 & Primary fossil energy use \\
\hline 32 & Secondary energy use \\
\hline 27 & Net energy indicator \\
\hline 33 & Energy saving potential \\
\hline 25 & Energy savings \\
\hline 24 & Specific energy consumption \\
\hline 34 & Total energy consumption \\
\hline 36 & Energy ratio \\
\hline 35 & Energy efficiency (1) \\
\hline 35 & Energy efficiency (2) \\
\hline 37 & Output renewability \\
\hline 63 & Percentage of plastic/paper/metals \\
\hline 64 & Percentage of waste diverted from disposal \\
\hline 65 & Percentage of hazardous waste diverted from disposal \\
\hline 66 & Percentage of non-hazardous waste diverted from disposal \\
\hline
\end{tabular}


Table 9. Cont.

\begin{tabular}{|c|c|}
\hline Number & Indicator \\
\hline 67 & Percentage of hazardous waste reused \\
\hline 68 & Percentage of hazardous waste recycled \\
\hline 69 & Percentage of hazardous waste sent to other recovery operations \\
\hline 70 & Percentage of non-hazardous waste reused \\
\hline 71 & Percentage of non-hazardous waste recycled \\
\hline 72 & Percentage of non-hazardous waste sent to other recovery operations \\
\hline 73 & Percentage of waste reused on site \\
\hline 73 & Percentage of waste recycled on site \\
\hline 73 & Percentage of waste recovered on site \\
\hline 74 & Percentage of waste directed to disposal \\
\hline 76 & Percentage of hazardous waste directed to disposal \\
\hline 75 & Percentage of non-hazardous waste directed to disposal \\
\hline 77 & Percentage of hazardous waste directed to incinerator \\
\hline 77 & Percentage of hazardous waste directed to landfilling \\
\hline 77 & Percentage of hazardous waste directed to other disposal operations \\
\hline 77 & Percentage of non-hazardous waste directed to incinerator \\
\hline 77 & Percentage of waste directed to landfilling \\
\hline 78 & Percentage of waste directed to other disposal operation \\
\hline 79 & Percentage of hazardous waste disposed on site \\
\hline 80 & Percentage of non-hazardous waste disposed on site \\
\hline 55 & Percentage of acidifying substances \\
\hline 56 & Percentage of greenhouse gases (GHG) \\
\hline 57 & Percentage of ozone depleting substances (ODS) \\
\hline 58 & Percentage of persistent organic pollutants (POP) \\
\hline 59 & Percentage of volatile organic compounds (VOC) \\
\hline 60 & Percentage of hazardous air pollutants (HAP) \\
\hline 61 & Percentage of particulate matter (PM) \\
\hline 10 & Percentage renewable materials used \\
\hline 11 & Percentage of non-renewable materials used \\
\hline 40 & Percentage of total recycled input materials \\
\hline 10 & Percentage of restricted substances (e.g., REACH) \\
\hline 50 & $\begin{array}{l}\text { Percentage of water withdrawn from the following sources: (i) surface water, } \\
\text { (ii) ground, (iii) water, (iv)seawater, (v) third-party water }\end{array}$ \\
\hline 51 & Percentage of water reused/recycled by the organization \\
\hline
\end{tabular}


Table 9. Cont.

\begin{tabular}{|c|c|}
\hline Number & Indicator \\
\hline 53 & $\begin{array}{l}\text { Percentage of water discharge to the following sources: (i) surface water, (ii) ground, } \\
\text { (iii) water, (iv)seawater, (v) third-party water }\end{array}$ \\
\hline 54 & $\begin{array}{c}\text { Percentage of fresh water ( } \leq 1000 \mathrm{mg} / \mathrm{L} \text { Total Dissolved Solids) discharge for each } \\
\text { destination }\end{array}$ \\
\hline 46 & $\begin{array}{l}\text { Percentage of renewable energy consumption generated by the following sources: } \\
\text { (i) hydroelectric, (ii) biomass, (iii) solar, (iv) wind }\end{array}$ \\
\hline 47 & $\begin{array}{c}\text { Percentage of non-renewable energy consumption generated by the following } \\
\text { sources: (i) natural gas, (ii) coal, (iii) other fossil fuels }\end{array}$ \\
\hline 15 & Total electric consumption \\
\hline 43 & Total heating consumption \\
\hline 44 & Total cooling consumption \\
\hline 45 & Total steam consumption \\
\hline
\end{tabular}

Indicator's List Filtering Based Industrial Workshops

The indicator selection activity has continued with the development of a data-gathering sheet to collect further information about LCA activities and identify already-measured indicators for further examination within the framework. The industrial companies were asked to create a map of the indicators currently being measured, as well as the environmental assessment methods and tools currently being employed. Thanks to the information collected, dedicated workshops were organized and structured for each industrial case to define the environmental indicators to use as a basis for the framework of sustainability management at the company and production level. The workshops have been structured around two central points. The first focused on the introduction of the factory features and the theoretical background of LCA and LCC methodologies; the second on the discussion of the framing conditions that aided in understanding each company's current LCA-LCC situation and highlighted the gaps that needed to be addressed to implement and/or improve LCA and LCC analysis. Each workshop was structured differently to keep the discussion focused on the topics of highest interest as determined by the responses and information provided during industrial case interviews. Then, the data were analyzed to identify the company's focus objective concerning the predefined targets. The development of the five workshops highlighted the strong relationship between the current state of the various industrial cases and the possible indicators that can be easily implemented and calculated. The selected indicators also consider the subsequent application of ancillary technologies for data collection, which are necessary to allow an immediate application of the indicators. The preliminary analysis of the workshop's result provided a clear view of the possible indicators to be used, their management, and calculation within the company. Next, the leading indicators on which to base the decision-making framework were divided and selected.

A deep analysis of the results of the interviews and workshops with the industrial cases revealed that the technological maturity of the pilot companies varies considerably. The level of IoT in production processes, the type of machinery involved, the company's attitude towards sustainability and environmental impact issues, along with the optimization of energy consumption, strongly influence the framework's structure and the list of sustainability indicators to be used.

By prioritizing the environmental sustainability KPIs highlighted by the industrial cases, it was possible to select seven lead indicators to build a breakdown structure delving into the details of the individual impact. These indicators are discussed in more detail in the following section of this paper. This approach makes it possible to compensate for the 
different levels of detail of the data present in the companies, thus reaching the appropriate level. The breakdown structure defined for each lead indicator also considers the various levels' calculability and the granularity of the indicators.

From the economic sustainability point of view, the interviews and workshops paved the way for the development of the cost indicators and framework. Firstly, a map the company's current needs and requirements regarding economic sustainability and the challenges that they are tackling was carried out. Secondly, the cost drivers and critical areas that require attention in each pilot company were identified by using the cost breakdown structure (CBS) approach. The hierarchical method used to define cost and related indicators promotes recognition of all relevant costs, whether direct or indirect. The analysis also itemized relevant IT systems that can provide data for LCCA and examined the LCCA data availability and accessibility in the industrial companies. The workshops and interviews produced a concrete mapping and hierarchy of costs of the production process and assets in the industrial companies. The workshops can also be used as a basis for data collection. The proposed framework and related cost indicators cover all life cycle phases-from the design and acquisition phase to the retirement phase of the production assets. It is not only applicable to analyze the total life cycle cost, but also to reduce cost of production process and the assets in question.

\subsection{Structuring KPIs and PIs in a Framework}

Based on the literature review of possible KPI for the assessment of sustainability at the factory level and the results obtained from the activities carried out with the industrial cases, a framework containing a list of indicators has been developed. The list of indicators is suggested based on the main idea for a sustainability assessment of the manufacturing process for different companies. Furthermore, the indicators are suggested to be universally applicable for all types of companies within the industrial sectors represented by the industrial cases examined. The development of the framework has also taken into account the three main aspects formulated by Steffen and Noone [72] for developing a framework for manufacturing sustainability: the inclusion of the full scope of sustainable manufacturing, including all drivers and barriers, to reflect the relationship between manufacturing and the environmental goal, and to allocate the absolute target. Bey [73] proposed that high-level aims should be continuously broken down into low-level targets to define the framework's structure. Therefore, the objective of this chapter has to design the framework that will support the optimization of company performance under sustainability perspectives.

Following the state-of-the-art analysis in the first part of this chapter, the final indicators framework is organized into the environmental and economic areas. First, provide a two-level vision (inventory and impact) where inventory indicators are split into five categories (materials, energy, water, emissions, and waste), according to GRI 300. For each category, at least one major KPI is identified allowing for the definition of a list of subindicators to obtain an overview of all the parameters contributing to each KPI. This has been done in order to provide companies with different possible levels of granularity for the analysis of their performances, ranging from a high-level vision (e.g., the total $\mathrm{kg}$ of wastes generated), to a more detailed one (e.g., the quantity of the hazardous material reused). Regarding impact indicators, the starting list created from the PEF and OEF of 16 indicators has been reduced to 7 by the introduction of the EPD. It is important to highlight that the inventory indicators in the framework are based on direct inventory data, meaning that only the input and output flows concerning the unit processes directly managed by the company (typically production data) are considered. This eases the collection phase, at the same time assuring the compilation of valuable indicators of the possible actions to be implemented to reduce natural resource use and the generated emissions. A view of the possible indirect effects is guarantee in the developed framework by the impact level that is evaluated using a life cycle perspective.

Regarding the interviews and workshop results, the most important economic indicators are related to costs and profitability. Broadly, there are two major cost indicators by 
which production assets and the IoT solutions integrated into manufacturing processes are to be evaluated: initial costs (CAPEX indicators) and future costs (OPEX indicators). Initial costs are all costs incurred prior to the deployment of the solution. Future costs are all costs incurred after the deployment of the solution. For energy efficiency issues, the benefit is largely the cost savings resulting from the deployment of novel IoT technologies. In general, the profitability indicators are used to analyze the comparison scenarios before and after the solution deployments. The cost savings provided by the novel solutions should be at least as good as the return target for the capital (investment costs).

Considering that the framework gives a snapshot of the company, it is important to underline the value of dynamic variation indicators to assess the performance comparing different periods. Thus, each major KPI will be supported by a variation index showing the difference between time spans.

\subsubsection{Inventory Indicators}

As mentioned in the previous introduction, the initial list of indicators has been skimmed and each classified to a specific environmental category-GRI 300: Environmental Disclosure. For each area, the general description, the graphic structure, and the table containing the mathematical formulas of each KPI and sub-indicator is provided.

\section{Direct Waste}

Waste can be generated during the organization's own activities, for example, during the production of its product and the delivery of services. When inadequately managed, waste can have significant negative impacts on the environment and human health. These impacts often extend beyond locations where waste is generated and discarded. The resources and materials contained in waste that is incinerated or landfilled are lost to future use, which accelerates their depletion. Figure 2 reports the structure of direct waste indicators.

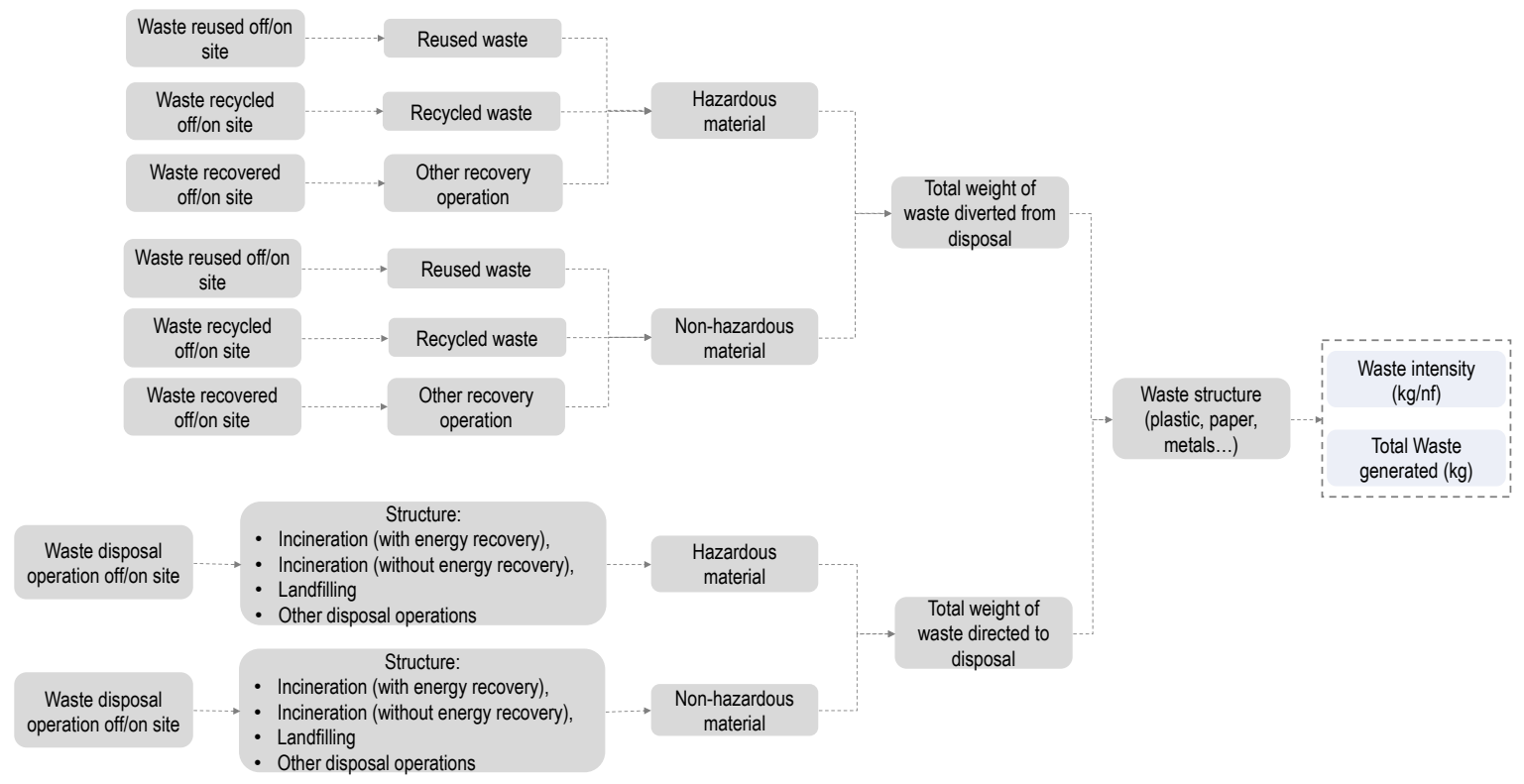

Figure 2. The direct-waste data structure.

The main KPIs selected are total waste generated and waste intensity. The latter is used for a better understanding of performance, since the normalization factor (nf) allows for the tracking of measures, usually depending on production volume. Then, in order to have a better view of the topic, it is suggested to defined the waste structure according to the different types of waste (plastic, paper, metal). Table 10 provides the formulas for the previously presented indicators. 
Table 10. Direct waste indicators-high level indicators.

\begin{tabular}{cccc}
\hline $\mathbf{N r}$ & Indicator & Formula & Unit \\
\hline 62 & Total waste generated & - & $\mathrm{kg}$ \\
\hline 19 & Waste intensity & $\frac{\text { Total waste generated }(\mathrm{kg})}{\text { normalisation factor }}$ & $\mathrm{kg} / \mathrm{nf}$ \\
\hline 63 & $\begin{array}{c}\text { Percentage of } \\
\text { plastic/paper } / \text { metals }\end{array}$ & $\frac{\text { total plastic/ paper } / \text { metals }(\mathrm{kg})}{\text { total waste generated }(\mathrm{kg})}$ & $\%$ \\
\hline
\end{tabular}

After the defining of waste structure, two branches were identified. The first, related to waste diverted from disposal, concerns the total volume of waste sent to recovery operations. Then, this is divided into hazardous and non-hazardous waste, defining the structure of the recovery operations (reused, recycled, other) and lastly, the amount of waste which is recovered off/on site. Tables 11 and 12 provide the formulas for the indicators belonging to the two branches.

Table 11. Direct waste indicators-waste diverted from disposal.

\begin{tabular}{|c|c|c|c|}
\hline $\mathrm{Nr}$ & Indicator & Formula & Unit \\
\hline 64 & Percentage of waste diverted from disposal & $\frac{\text { total waste diverted from disposal }(\mathrm{kg})}{\text { total waste generated }(\mathrm{kg})} * 100$ & $\%$ \\
\hline 65 & $\begin{array}{c}\text { Percentage of hazardous waste diverted } \\
\text { from disposal }\end{array}$ & $\frac{\text { total hazardous waste diverted from disposal }(\mathrm{kg})}{\text { total waste diverted from disposal }(\mathrm{kg})} * 100$ & $\%$ \\
\hline 66 & $\begin{array}{c}\text { Percentage of non-hazardous waste diverted } \\
\text { from disposal }\end{array}$ & $\frac{\text { total non-hazardous waste diverted from disposal }(\mathrm{kg})}{\text { total waste diverted from disposal }(\mathrm{kg})} * 100$ & $\%$ \\
\hline 67 & Percentage of hazardous waste reused & $\frac{\text { total hazardous waste reused }(\mathrm{kg})}{\text { total hazardous waste diverted from disposal }(\mathrm{kg})} * 100$ & $\%$ \\
\hline 68 & Percentage of hazardous waste recycled & $\frac{\text { total hazardous waste recyled }(\mathrm{kg})}{\text { total hazardous waste diverted from disposal }} * 100$ & $\%$ \\
\hline 69 & $\begin{array}{c}\text { Percentage of hazardous waste sent to other } \\
\text { recovery operations }\end{array}$ & $\frac{\text { total waste sent to other recovery operations }(\mathrm{kg})}{\text { total hazardous waste diverted from disposal }(\mathrm{kg})} * 100$ & $\%$ \\
\hline 70 & Percentage of non-hazardous waste reused & $\frac{\text { total non-hazardous waste reused }(\mathrm{kg})}{\text { total non-hazardous waste diverted from disposal }(\mathrm{kg})} * 100$ & $\%$ \\
\hline 71 & Percentage of non-hazardous waste recycled & $\frac{\text { total non-hazardous waste recycled }(\mathrm{kg})}{\text { total non-hazardous waste diverted from disposal }(\mathrm{kg})} * 100$ & $\%$ \\
\hline 72 & $\begin{array}{l}\text { Percentage of non-hazardous waste sent to } \\
\text { other recovery operations }\end{array}$ & $\frac{\text { total non-hazardous waste sent to other recovery operations }(\mathrm{kg})}{\text { total non-hazardous waste diverted from disposal }(\mathrm{kg})} * 100$ & $\%$ \\
\hline 73 & Percentage of waste reused on site & $\frac{\text { total waste reused on site }(\mathrm{kg})}{\text { total waste reused }(\mathrm{kg})}$ & $\%$ \\
\hline 73 & Percentage of waste recycled on site & $\frac{\text { total waste recycled on site }(\mathrm{kg})}{\text { total waste recycled }(\mathrm{kg})}$ & $\%$ \\
\hline 73 & Percentage of waste recovered on site & $\frac{\text { total waste recovered on site }(\mathrm{kg})}{\text { total waste recovored }(\mathrm{kg})}$ & $\%$ \\
\hline
\end{tabular}

Table 12. Direct waste indicators-waste directed to disposal.

\begin{tabular}{|c|c|c|c|}
\hline $\mathrm{Nr}$ & Indicator & Formula & Unit \\
\hline 74 & Percentage of waste directed to disposal & $\frac{\text { total waste directed from disposal }(\mathrm{kg})}{\text { total waste generated }(\mathrm{kg})} * 100$ & $\%$ \\
\hline 76 & $\begin{array}{c}\text { Percentage of hazardous waste directed to } \\
\text { disposal }\end{array}$ & $\frac{\text { total hazardous waste directed from disposal }(\mathrm{kg})}{\text { total waste directed from disposal }(\mathrm{kg})} * 100$ & $\%$ \\
\hline 75 & $\begin{array}{l}\text { Percentage of non-hazardous waste directed } \\
\text { to disposal }\end{array}$ & $\frac{\text { total non-hazardous waste directed from disposal }(\mathrm{kg})}{\text { total waste directed from disposal }(\mathrm{kg})} * 100$ & $\%$ \\
\hline 77 & $\begin{array}{c}\text { Percentage of hazardous waste directed to } \\
\text { incinerator }\end{array}$ & $\frac{\text { total hazardous waste directed to incinerator }(\mathrm{kg})}{\text { total hazardous waste directed to disposal }(\mathrm{kg})}$ & $\%$ \\
\hline 77 & $\begin{array}{c}\text { Percentage of hazardous waste directed to } \\
\text { landfilling }\end{array}$ & $\frac{\text { total hazardous waste directed to landfilling }(\mathrm{kg})}{\text { total hazardous waste directed to disposal }(\mathrm{kg})} * 100$ & $\%$ \\
\hline
\end{tabular}


Table 12. Cont.

\begin{tabular}{|c|c|c|c|}
\hline $\mathrm{Nr}$ & Indicator & Formula & Unit \\
\hline 77 & $\begin{array}{l}\text { Percentage of hazardous waste directed to } \\
\text { other disposal operations }\end{array}$ & $\frac{\text { total hazardous waste directed to other disposal operations }(\mathrm{kg})}{\text { total hazardous waste directed to disposal }(\mathrm{kg})} * 100$ & $\%$ \\
\hline 77 & $\begin{array}{l}\text { Percentage of non-hazardous waste directed } \\
\text { to incinerator }\end{array}$ & $\frac{\text { total non-hazardous waste directed to incineror }(\mathrm{kg}}{\text { total non-hazardous waste directed to disposal }(\mathrm{kg})}$ & $\%$ \\
\hline 77 & Percentage of waste directed to landfilling & $\frac{\text { total non-hazardous waste directed to landfilling }(\mathrm{kg})}{\text { total non-hazardous waste directed to disposal }(\mathrm{kg})} * 100$ & $\%$ \\
\hline 78 & $\begin{array}{l}\text { Percentage of waste directed to other } \\
\text { disposal operation }\end{array}$ & $\frac{\text { total non-hazardous waste directed to other disposal operations }(\mathrm{kg})}{\text { total non-hazardous waste directed to disposal }(\mathrm{kg})} * 100$ & $\%$ \\
\hline 79 & $\begin{array}{l}\text { Percentage of hazardous waste disposed on } \\
\text { site }\end{array}$ & $\frac{\text { total hazardous waste disposed on site }(\mathrm{kg})}{\text { total hazardous waste directed to disposal }(\mathrm{kg})} * 100$ & $\%$ \\
\hline 80 & $\begin{array}{l}\text { Percentage of non-hazardous waste } \\
\text { disposed on site }\end{array}$ & $\frac{\text { total non-hazardous waste disposed on site }(\mathrm{kg})}{\text { total non-hazardous waste directed to disposal }(\mathrm{kg})} * 100$ & $\%$ \\
\hline
\end{tabular}

The second branch is related to waste directed for disposal after first being classified as hazardous and non-hazardous waste; these are broken down into their disposal operations (incinerator, landfilling, other). Lastly, waste disposal operations off/on site are measured.

\section{Direct Emissions}

Emissions in the air are the discharge of substances from a source into the atmosphere. The main types of emissions include greenhouse gases (GHG), ozone-depleting substances (ODS), and nitrogen oxides $\left(\mathrm{NO}_{\mathrm{x}}\right)$ and sulphur oxides $\left(\mathrm{SO}_{\mathrm{x}}\right)$. These pollutants have adverse effects on the climate, ecosystem, air quality, habitats, agriculture, and human health Recently, the deterioration of air quality and acidification have led to local and international regulations to control emissions of these pollutants. Other significant air emissions include, for example, persistent organic pollutants or particulate matter, as well as air emissions that are regulated under international conventions and/or national laws or regulations, including those listed on an organization's environmental permits [48]. The KPIs structure is reported in Figure 3, while the indicators with the formulas are reported in Table 13.

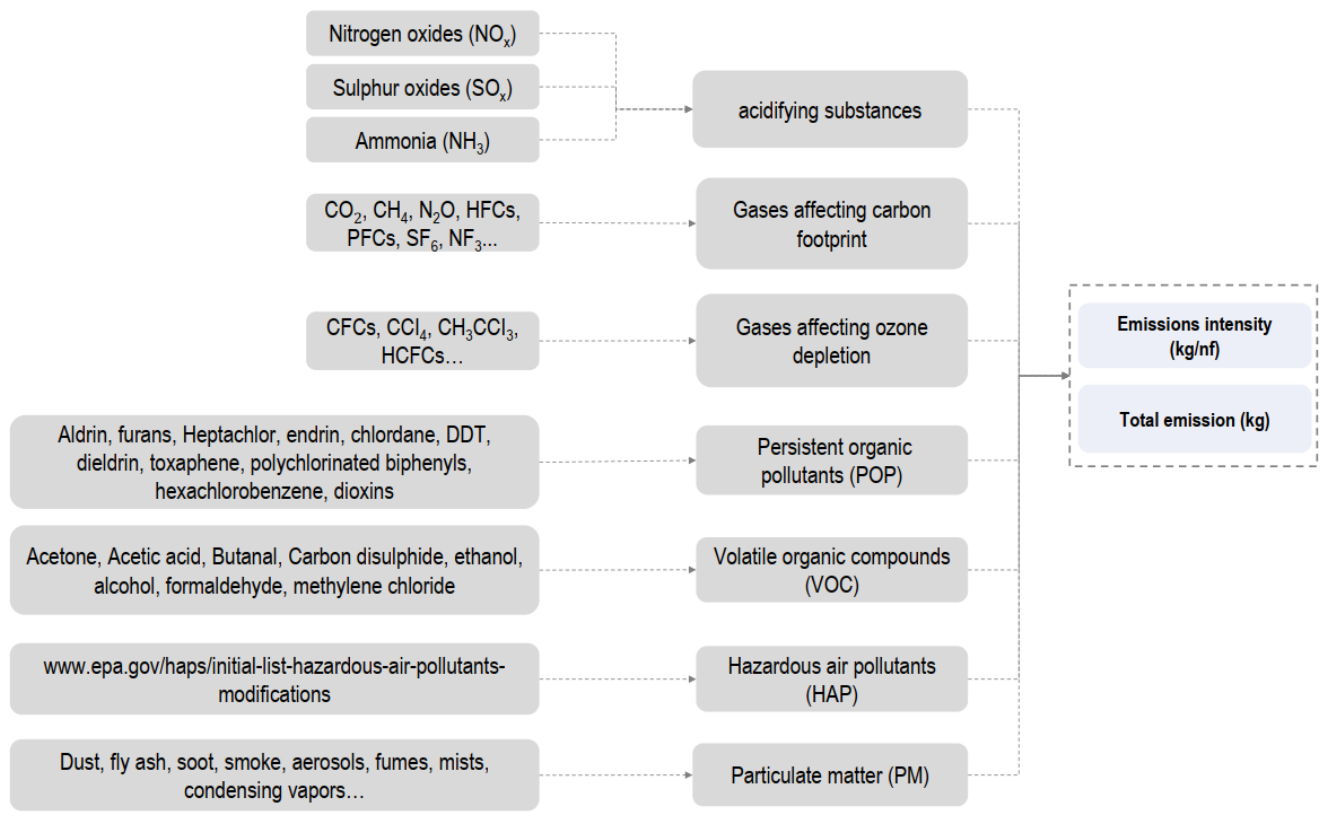

Figure 3. The direct emissions data structure. 
Table 13. Direct emissions-indicators.

\begin{tabular}{|c|c|c|c|}
\hline $\mathrm{Nr}$ & Indicator & Formula & Unit \\
\hline 1 & Total emissions & - & $\mathrm{kg}$ \\
\hline 20 & Emissions intensity & $\frac{\text { total emissions }}{\text { normalization factor }} * 100$ & $\mathrm{~kg} / \mathrm{nf}$ \\
\hline 55 & Percentage of acidifying substances & $\frac{\text { total acidifying substances }\left(\mathrm{NO}_{x}, \mathrm{CO}_{x}, \ldots\right)(\mathrm{kg})}{\text { total emissions }(\mathrm{kg})} * 100$ & $\%$ \\
\hline 56 & Percentage of greenhouse gases (GHG) & $\frac{\text { total } \mathrm{GHG}\left(\mathrm{CO}_{2}, \mathrm{CH}_{4}, \ldots\right)(\mathrm{kg})}{\text { total emissions }(\mathrm{kg})} * 100$ & $\%$ \\
\hline 57 & $\begin{array}{l}\text { Percentage of ozone depleting substances } \\
\text { (ODS) }\end{array}$ & $\frac{\text { total ODS }(C F C s . . .)(\mathrm{kg})}{\text { total emissions }(\mathrm{kg})} * 100$ & $\%$ \\
\hline 58 & $\begin{array}{l}\text { Percentage of persistent organic pollutants } \\
\text { (POP) }\end{array}$ & $\frac{\text { total POP (aldrin, furans...) }(\mathrm{kg})}{\text { total emissions }(\mathrm{kg})} * 100$ & $\%$ \\
\hline 59 & $\begin{array}{l}\text { Percentage of volatile organic compounds } \\
\text { (VOC) }\end{array}$ & $\frac{\text { total VOC (acetone, athanol...) }(\mathrm{kg})}{\text { total emissions }(\mathrm{kg})} * 100$ & $\%$ \\
\hline 60 & $\begin{array}{l}\text { Percentage of hazardous air pollutants } \\
\text { (HAP) }\end{array}$ & $\frac{\text { total HAP (acrolein, chlorine...) }(\mathrm{kg})}{\text { total emissions }(\mathrm{kg})} * 100$ & $\%$ \\
\hline 61 & Percentage of particulate matter (PM) & $\frac{\text { total PC (dust, fly ash...) }(\mathrm{kg})}{\text { total emissions }(\mathrm{kg})} * 100$ & $\%$ \\
\hline
\end{tabular}

The main KPIs selected to be visualized are total emissions and emissions intensity. Then, with the aim of better understanding company performance, the emissions structure has been defined according to GRI 305 standards.

Direct Inputs Materials

The inputs used to manufacture products and services can be renewable materials, such as wood, cotton, and water; or non-renewable materials, such as metals, natural gas, and oil. Both can be composed of recycled or virgin materials. The indicators presented allow for the measurement of the organization's dependence on natural resources, as well as the impact on their depletion. The main KPIs and sub-indicators' structure is reported in Figure 4, while the mathematical formulas are reported in Table 14.

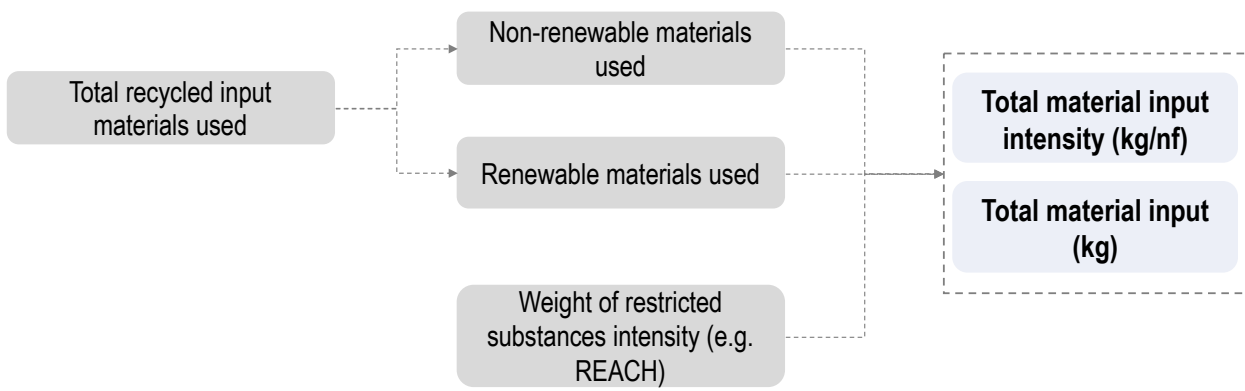

Figure 4. The direct material data structure.

Table 14. The direct material-indicators.

\begin{tabular}{|c|c|c|c|}
\hline $\mathrm{Nr}$ & Indicator & Formula & Unit \\
\hline 38 & Total material input & - & $\mathrm{kg}$ \\
\hline 39 & Total material input intensity & $\frac{\text { total material input }(\mathrm{kg})}{\text { normalization factor }}$ & $\mathrm{kg} / \mathrm{nf}$ \\
\hline 10 & Percentage of renewable materials used & $\frac{\text { total renewable materials used }(\mathrm{kg})}{\text { total material input }(\mathrm{kg})} * 100$ & $\%$ \\
\hline 11 & Percentage of non-renewable materials used & $\frac{\text { total non-renewable materials used }(\mathrm{kg})}{\text { total material input }(\mathrm{kg})} * 100$ & $\%$ \\
\hline 40 & Percentage of total recycled input materials & $\frac{\text { total recycled materials used }(\mathrm{kg})}{\text { total material input }(\mathrm{kg})} * 100$ & $\%$ \\
\hline 10 & Percentage of restricted substances (e.g., REACH) & $\frac{\text { total restricted substances by regulations }(\mathrm{kg})}{\text { total material input }(\mathrm{kg})} * 100$ & $\%$ \\
\hline
\end{tabular}


The main KPIs selected are total material input and material input intensity. Then, a split into renewable and non-renewable materials is fundamental to provide a better view of the distribution of input materials within the company. Lastly, recycled materials are also considered, along with restricted substances according to REACH regulations.

\section{Direct Water}

The function of the ecosystem can be impacted in numerous ways by the amount of water withdrawn and consumed by an organization, as well as the quality of its discharges. Direct impact on a water basin can have an even broader impact on the quality of life in an area, causing social and economic consequences for local communities and indigenous people. The list of indicators presented allows for a comprehensive understanding of water use and how it can benefit the ecosystem, other water users, or the organization itself. The main KPIs and sub-indicators are presented in Figure 5, while the mathematical formulas are reported in Tables 15 and 16.

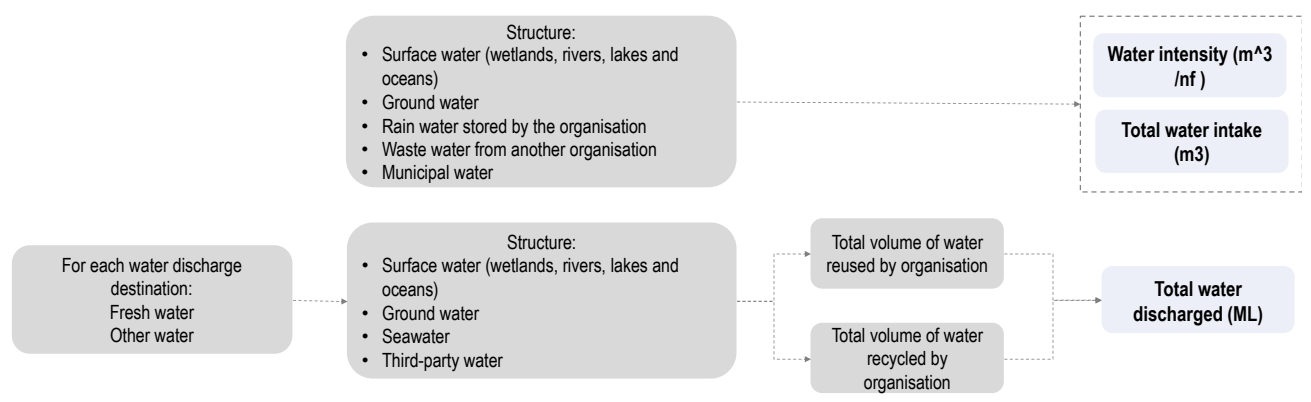

Figure 5. Direct water data structure.

Table 15. Direct water indicators-water intake.

\begin{tabular}{cccc}
\hline $\mathbf{N r}$ & Indicator & Formula & Unit \\
\hline 49 & Total water intake & ML \\
\hline 18 & Water intensity & $\frac{\text { total water intake }(\mathrm{ML})}{\text { normalization factor }}$ & ML/nf \\
\hline 50 & $\begin{array}{c}\text { Percentage of water withdrawn from the following sources: } \\
\text { (i) surface water, (ii) ground, (iii) water, (iv) seawater, } \\
\text { (v) third-party water }\end{array}$ & $\begin{array}{ll}\text { total water intake from a source } i(\mathrm{~kg}) \\
\text { total water intake (ML) }\end{array}$ & \\
\hline
\end{tabular}

Table 16. Direct water indicators-water discharge.

\begin{tabular}{|c|c|c|c|}
\hline $\mathrm{Nr}$ & Indicator & Formula & Unit \\
\hline 52 & Total water discharge & - & ML \\
\hline 51 & $\begin{array}{c}\text { Percentage of water reused/recycled by the } \\
\text { organization }\end{array}$ & $\frac{\text { total water reused / recycled }(\mathrm{ML})}{\text { total water discharge }(\mathrm{ML})} * 100$ & $\%$ \\
\hline 53 & $\begin{array}{l}\text { Percentage of water discharge to the following sources: } \\
\text { (i) surface water, (ii) ground, (iii) water, (iv) seawater, } \\
\text { (v) third-party water }\end{array}$ & $\frac{\text { total water discharge to a source } i(\mathrm{ML})}{\text { total water discharge }(\mathrm{ML})} * 100$ & $\%$ \\
\hline 54 & $\begin{array}{l}\text { Percentage of fresh water ( } \leq 1000 \mathrm{mg} / \mathrm{L} \text { Total } \\
\text { Dissolved Solids) discharge for each destination }\end{array}$ & $\frac{\text { total fresh water discharge }(\mathrm{ML})}{\text { total water discharge }(\mathrm{ML})} * 100$ & $\%$ \\
\hline
\end{tabular}

The main KPIs selected are total water intake, water intensity, and total water discharge. The first two refer to input water where a classification based on the source (surface water, ground water... ) is needed. 
The third indicator refers to output water, considering the distribution of final destination (surface water, ground water, etc.) as well as the quality of the water, where, according to GRI 303, fresh water contains less than $1000 \mathrm{mg} / \mathrm{L}$ of total dissolved solids.

\section{Direct Energy}

Energy can be consumed by an organization in various forms, such as electricity, fuel, cooling, heating, or steam. Energy can be self-generated or purchased from external non-renewable (oil, natural gas, or coal) or renewable (solar, wind, or hydro) sources. The sets of indicators presented allow an organization to better understand its consumptions, encouraging energy-efficient practices with the aim of lowering the organization's overall environmental footprint.

According to GRI 302, energy consumption can also occur throughout upstream and downstream activities connected with an organization's operations, including the product use phase and end-of-life phases. Considering that the context in which the framework has been developed, only consumption directly connected to manufacturing activities is taken into account, while the life cycle vision is considered at the impact level.

The main KPIs and sub-indicators are presented in Figure 6.

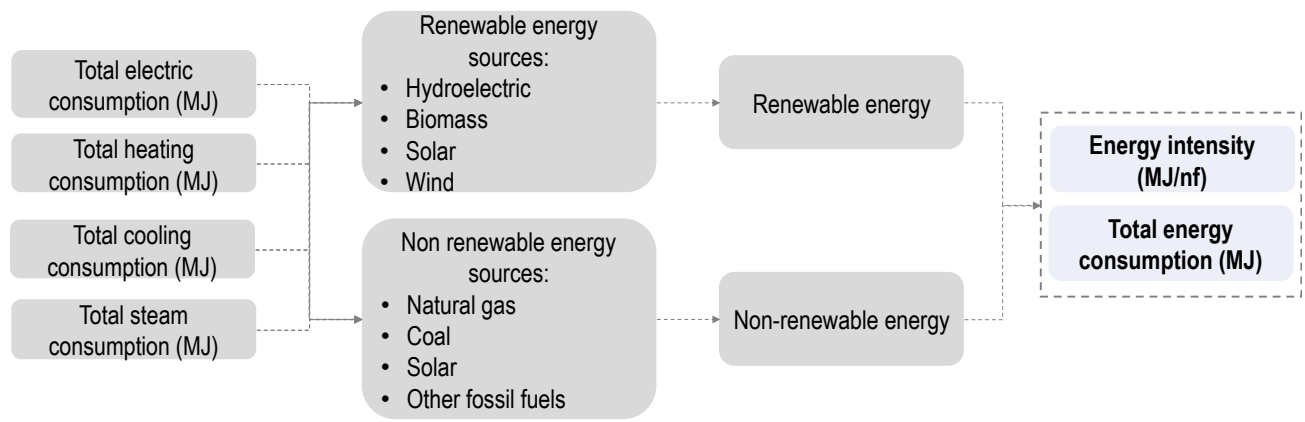

Figure 6. Direct energy data structure.

The main KPIs selected to be visualized are total energy consumption and energy intensity. Then, a classification is made between renewable and non-renewable energy. Last, the consumption for each form of energy is reported. Table 17 provides the list of indicators with the mathematical formulas.

Table 17. Direct energy—indicators.

\begin{tabular}{|c|c|c|c|}
\hline $\mathrm{Nr}$ & Indicator & Formula & Unit \\
\hline 34 & Total energy consumption & - & MJ \\
\hline 14 & Energy intensity & $\frac{\text { total energy consumption }(\mathrm{MJ})}{\text { normalization factor }} * 100$ & $\mathrm{MJ} / \mathrm{nf}$ \\
\hline 21 & Percentage of renewable energy consumption & $\frac{\text { total renewable energy consumption }(\mathrm{MJ})}{\text { total energy consumption }(\mathrm{MJ})} * 100$ & $\%$ \\
\hline 46 & $\begin{array}{l}\text { Percentage of renewable energy consumption } \\
\text { generated by the following sources: (i) hydroelectric, } \\
\text { (ii) biomass, (iii) solar, (iv) wind }\end{array}$ & $\frac{\text { total renewable energy generated by a source } i(\mathrm{MJ})}{\text { total energy consumption }(\mathrm{MJ})} * 100$ & $\%$ \\
\hline 29 & Percentage of non-renewable energy consumption & $\frac{\text { total non-renewable energy consumption }(\mathrm{MJ})}{\text { total energy consumption }(\mathrm{MJ})} * 100$ & $\%$ \\
\hline 47 & $\begin{array}{l}\text { Percentage of non-renewable energy consumption } \\
\text { generated by the following sources: (i) natural gas, (ii) } \\
\text { coal, (iii) other, fossil fuels }\end{array}$ & $\frac{\text { total non-renewable energy generated by a source } i(\mathrm{MJ})}{\text { total energy consumption }(\mathrm{MJ})} * 100$ & \\
\hline 15 & Total electric consumption & - & MJ \\
\hline 43 & Total heating consumption & - & MJ \\
\hline 44 & Total cooling consumption & - & MJ \\
\hline 45 & Total steam consumption & - & MJ \\
\hline
\end{tabular}




\subsubsection{Impact Indicators}

To help evaluate the environmental performance of products and organizations from a life-cycle point of view, PEF and OEF provide a list of 16 indicators that help in assessing environmental impacts and identifying potential improvement actions. While PEF methodology targets individual products or services, OEF consider the organization as a whole, i.e., the entire supply chain of a product or service from raw materials extraction to the end-of-life phase.

As mentioned in Section 2.1.2, EPD gives a default list of six indicators and methods believed to be the most significative environmental KPIs. Considering the high number of indicators, there was a need to reduce the list selecting only the indicators most relevant to the manufacturing sector. This is the reason why, in Table 18, PEF, OEF, and EPD indicators have been mapped, and only the KPIs considered by all of the three standards have been included in the framework. It is worth noting that the EPD indicators are a subgroup of those in PEF and OEF, so only EPD KPIs have been selected. Lastly, it is important to specify that the computation of the life cycle impact assessment does not depend on the number of indicators, so, the choice of six indicators (the blue cells in Table 18) is for relevance and visualization purposes.

Table 18. The mapping and selection of impact indicators and characterization models.

\begin{tabular}{|c|c|c|c|c|c|}
\hline Impact Category & $\begin{array}{l}\text { Impact Category } \\
\text { Indicator }\end{array}$ & Unit & Characterization Model & PEF/OEF & EPD \\
\hline Climate change, total & $\begin{array}{l}\text { Radiative forcing as } \\
\text { global warming potential } \\
\text { (GWP100) }\end{array}$ & $\mathrm{kg} \mathrm{CO}_{2}$ eq. & $\begin{array}{l}\text { Baseline model of } 100 \text { years of the IPCC } \\
\text { (based on IPCC 2013)/GWP100, CML } 2001 \\
\text { Baseline }\end{array}$ & $x$ & $x$ \\
\hline Ozone depletion & depletion & kg CFC-11 eq. & $\begin{array}{c}\text { Steady-state ODPs as in (WMO } 2014+ \\
\text { integrations) }\end{array}$ & $x$ & \\
\hline $\begin{array}{l}\text { Human toxicity, } \\
\text { cancer }\end{array}$ & $\begin{array}{l}\text { Comparative Toxic Unit } \\
\text { for humans (CTUh) }\end{array}$ & CTUh & USEtox model 2.1 (Fankte et al., 2017) & $x$ & \\
\hline $\begin{array}{l}\text { Human toxicity, } \\
\text { non-cancer }\end{array}$ & $\begin{array}{l}\text { Comparative Toxic Unit } \\
\text { for humans (CTUh) }\end{array}$ & CTUh & USEtox model 2.1 (Fankte et al., 2017) & $x$ & \\
\hline Particulate matter & Impact on human health & disease incidence & $\begin{array}{l}\text { PM method recommended by UNEP } \\
\text { (UNEP 2016) }\end{array}$ & $x$ & \\
\hline $\begin{array}{l}\text { Ionizing radiation, } \\
\text { human health }\end{array}$ & $\begin{array}{l}\text { Human exposure } \\
\text { efficiency relative to U235 }\end{array}$ & kBq U235 eq. & $\begin{array}{l}\text { Human health effect model as developed } \\
\text { by Dreicer et al., } 1995 \text { (Frischknecht et al., } \\
\text { 2000) }\end{array}$ & $x$ & \\
\hline $\begin{array}{l}\text { Photochemical ozone } \\
\text { formation, human } \\
\text { health }\end{array}$ & $\begin{array}{l}\text { Tropospheric ozone } \\
\text { concentration increase }\end{array}$ & kg NMVOC eq. & $\begin{array}{l}\text { LOTOS-EUROS model (Van Zelm et al., } \\
\text { 2008) as implemented in ReCiPe } \\
\text { 2008/POFP, LOTOS-EUROS as applied in } \\
\text { ReCiPe 2008 }\end{array}$ & $x$ & $x$ \\
\hline Acidification & $\begin{array}{l}\text { Accumulated Exceedance } \\
\text { (AE) }\end{array}$ & mol H + eq. / kg PO43 eq. & $\begin{array}{l}\text { Accumulated Exceedance (Seppälä et al. } \\
\text { 2006, Posch et al., 2008)/ AP, CML } 2001 \\
\text { non-baseline (fate non included) }\end{array}$ & $x$ & $x$ \\
\hline $\begin{array}{l}\text { Eutrophication, } \\
\text { terrestrial }\end{array}$ & $\begin{array}{l}\text { Accumulated Exceedance } \\
\text { (AE) }\end{array}$ & mol $\mathrm{N}$ eq. & $\begin{array}{l}\text { Accumulated Exceedance (Seppälä et al. } \\
\text { 2006, Posch et al., 2008) }\end{array}$ & $x$ & \\
\hline $\begin{array}{l}\text { Eutrophication, } \\
\text { freshwater }\end{array}$ & $\begin{array}{l}\text { Fraction of nutrients } \\
\text { reaching freshwater end } \\
\text { compartment }(P)\end{array}$ & kg P eq. & $\begin{array}{l}\text { EUTREND model (Struijs et al., 2009) as } \\
\text { implemented in ReCiPe }\end{array}$ & $x$ & \\
\hline $\begin{array}{l}\text { Eutrophication, } \\
\text { marine }\end{array}$ & $\begin{array}{l}\text { Fraction of nutrients } \\
\text { reaching marine end } \\
\text { compartment }(\mathrm{N})\end{array}$ & $\mathrm{kg} \mathrm{N}$ eq. & $\begin{array}{l}\text { EUTREND model (Struijs et al., 2009) as } \\
\text { implemented in ReCiPe }\end{array}$ & $x$ & \\
\hline $\begin{array}{l}\text { Ecotoxicity, } \\
\text { freshwater }\end{array}$ & $\begin{array}{l}\text { Comparative Toxic Unit } \\
\text { for ecosystems (CTUe) }\end{array}$ & CTUe & USEtox model 2.1 (Fankte et al., 2017) & $x$ & \\
\hline Land use & $\begin{array}{l}\text { Soil quality index } \\
\text { Biotic production } \\
\text { Erosion resistance } \\
\text { Mechanical filtration } \\
\text { Groundwater } \\
\text { replenishment }\end{array}$ & $\begin{array}{c}\text { Dimensionless }(\mathrm{pt}) \\
\mathrm{kg} \text { biotic production } \\
\mathrm{kg} \text { soil } \\
\mathrm{m}^{3} \text { water } \\
\mathrm{m}^{3} \text { groundwater }\end{array}$ & $\begin{array}{l}\text { Soil quality index based on LANCA (Beck } \\
\text { et al., } 2010 \text { and Bos et al. 2016) }\end{array}$ & $x$ & \\
\hline
\end{tabular}


Table 18. Cont.

\begin{tabular}{|c|c|c|c|c|c|}
\hline Impact Category & $\begin{array}{l}\text { Impact Category } \\
\text { Indicator }\end{array}$ & Unit & Characterization Model & PEF/OEF & EPD \\
\hline Water use & $\begin{array}{l}\text { User deprivation } \\
\text { potential } \\
\text { (deprivation-weighted } \\
\text { water consumption) }\end{array}$ & $\mathrm{m}^{3} \mathrm{H}_{2} \mathrm{O}$ eq. & $\begin{array}{l}\text { Available Water Remaining (AWARE) as } \\
\text { recommended by UNEP, 2016/AWARE } \\
\text { Method: WULCA recommendations on } \\
\text { characterization model for WSF 2015, } 2017\end{array}$ & $x$ & $x$ \\
\hline $\begin{array}{l}\text { Resource use, } \\
\text { minerals and metals }\end{array}$ & $\begin{array}{l}\text { Abiotic resource } \\
\text { depletion (ADP ultimate } \\
\text { reserves) }\end{array}$ & kg Sb eq. & $\begin{array}{l}\text { CML } 2002 \text { (Guinée et al., 2002) and van } \\
\text { Oers et al. 2002/ADP elements, CLM 2001, } \\
\text { baseline }\end{array}$ & $x$ & $x$ \\
\hline Resource use, fossils & $\begin{array}{l}\text { Abiotic resource } \\
\text { depletion-fossil fuels } \\
\text { (ADP-fossil) }\end{array}$ & MJ & $\begin{array}{c}\text { CML } 2002 \text { (Guinée et al., 2002) and van } \\
\text { Oers et al. 2002/ADP fossil fuels, CML } \\
\text { 2001, baseline }\end{array}$ & $x$ & $x$ \\
\hline
\end{tabular}

\subsubsection{Economic Indicators}

As discussed previously, the most relevant economic indicators can be divided into cost (CAPEX and OPEX) and profitability indicators. CAPEX are major investments and purchases that are designed to be used over the long term. When calculating production costs, CAPEX can be considered as an annualized investment cost and is allocated to various processes and further, to different machines. Annualized costs are calculated from the total capital cost, the lifetime of the production asset, and the interest rate. OPEX can be divided into direct and indirect costs and the related indicators. A direct cost is directly related to the production of specific products or services. Energy can be defined as a direct cost since electricity usage increases with the number of products manufactured. Electricity costs in production can be reduced e.g., by scheduling operations for off-peakdemand hours, if possible, upgrading inefficient and outdated equipment, performing scheduled maintenance periodically, and shopping for the best commercial electricity rates. Indirect costs include quality costs, inventory costs, and costs due to human errors. The high-level categorization of CAPEX and OPEX is presented in Figure 7. The most important profitability indicators which support judging and decision making with respect to economic and cost impacts are net present value (NPV) and payback period.

\begin{tabular}{|c|c|c|}
\hline & LCC (Life Cycle Cost) - Produc & \\
\hline $\begin{array}{c}\text { CAPEX } \\
\text { Ownership cost }\end{array}$ & $\begin{array}{c}\text { OPEX } \\
\text { Direct / explicit operating and maintenance cost }\end{array}$ & $\begin{array}{c}\text { OPEX } \\
\text { Indirect / implicit operating and maintenance cost }\end{array}$ \\
\hline
\end{tabular}

Figure 7. CAPEX and OPEX indicators.

The main selected lower-level indicators regarding CAPEX and OPEX are presented in the Table 19.

Table 19. Cost indicators.

\begin{tabular}{ccc}
\hline CAPEX & Direct OPEX & Indirect OPEX \\
\hline $\begin{array}{c}\text { Depreciation } / \text { annualized investment cost for } \\
\text { production assets }(€ / \mathrm{a}) .\end{array}$ & Material and component cost $(€ / \mathrm{a})$. & \\
Major asset enhancements and replacements & Production personnel labor cost $(€ / \mathrm{a})$. & Internal quality cost $(€ / \mathrm{a})$. \\
during lifetime $(€)$. & Energy cost $(€ / \mathrm{a})$. & Inventory cost $(€ / \mathrm{a})$. \\
Asset retirement cost $(€)$. & Other consumables $(€ / \mathrm{a})$. & Human errors $(€ / \mathrm{a})$. \\
Facilities capital cost. & Scheduled maintenance $(€ / \mathrm{a})$. & \\
Miscellaneous ownership costs. & Corrective maintenance $(€ / \mathrm{a})$. & \\
\hline
\end{tabular}




\subsection{The Framework}

Starting from 163 indicators extracted from frameworks presented by the literature and applying the selection criteria introduced in the methodology section, 20 KPIs have been defined for the sustainability assessment of manufacturing enterprises. The goal was to define a framework to help manufacturing companies assessing their use of resources, as well as their impacts on the environment. Since social sustainability was not considered, the indicators have been organized into environmental and economic sustainability. The first contains the following sub-categories: materials, energy, water, emissions, and waste, while the second contains: OPEX and CAPEX. Within the framework, 17 indicators belong to environmental dimensions and 3 indicators to the economic dimension. Since the framework has been validated within five industrial pilots, the selected indicators are valid for measuring the sustainability performance of manufacturing companies in terms of applicability, calculation, and relevance to the sector. The assignment of a "major" KPI for each category, especially for the environmental area, allows the visualization of the individually the behavior of a company for aspects related to the use of natural resources and materials, waste generation, energy management, and emissions. In addition, the structure of the KPIs presented in Section 3.3.1 makes it possible to exploit the obtained results strategically and not merely for monitoring purposes. This is because, through a backward approach, it is possible to investigate which individual parameters contribute to each major KPI, allowing the firm to identify the hotspots and act quickly. While the inventory indicators allow strategic action, the proposed set of impact indicators provides the company with an overview of the impacts generated on the environment. Generally, these provide a starting point for generating environmental labels, often geared toward obtaining environmental certifications.

In Table 20, each indicator is provided with the quantification method and unit of measurement.

Table 20. The main environmental and economic KPIs.

\begin{tabular}{|c|c|c|c|}
\hline $\mathrm{Nr}$ & Indicator & Formula & Unit \\
\hline 62 & Total waste generated & - & $\mathrm{kg}$ \\
\hline 19 & Waste intensity & $\frac{\text { total waste generated }(\mathrm{kg})}{\text { normalization factor }}$ & $\mathrm{kg} / \mathrm{nf}$ \\
\hline 1 & Total emissions & - & $\mathrm{kg}$ \\
\hline 20 & Emissions intensity & $\frac{\text { total emissions }(\mathrm{kg})}{\text { normalization factor }}$ & $\mathrm{kg} / \mathrm{nf}$ \\
\hline 38 & Total material input & - & $\mathrm{kg}$ \\
\hline 39 & Total material input intensity & $\frac{\text { total material input }(\mathrm{kg})}{\text { normalization factor }}$ & $\mathrm{kg} / \mathrm{nf}$ \\
\hline 49 & Total water intake & - & ML \\
\hline 18 & Water intensity & $\frac{\text { total water intake }}{\text { normalization factor }}$ & $\mathrm{ML} / \mathrm{nf}$ \\
\hline 52 & Total water discharge & - & ML \\
\hline 34 & Total energy consumption & - & MJ \\
\hline 14 & Energy intensity & $\frac{\text { total energy consumt pioin }(\mathrm{MJ})}{\text { normalization factor }}$ & $\mathrm{MJ} / \mathrm{nf}$ \\
\hline 116 & $\begin{array}{l}\text { Radioactive forcing as global } \\
\text { warming potential (GWP100) }\end{array}$ & LCA methodology & $\mathrm{kg} \mathrm{CO} 2$ eq. \\
\hline 123 & Accumulated exceedance & LCA methodology & $\mathrm{kg}$ PO43 eq \\
\hline
\end{tabular}


Table 20. Cont.

\begin{tabular}{cccc}
\hline 129 & $\begin{array}{c}\text { User deprivation potential } \\
\text { (deprivation-weighted water } \\
\text { consumption) }\end{array}$ & LCA methodology & $\mathrm{m}^{3} \mathrm{H}_{2} \mathrm{O}$ eq. \\
\hline 122 & $\begin{array}{c}\text { Tropospheric ozone } \\
\text { concentration increase }\end{array}$ & LCA methodology & kg NMVOC eq. \\
\hline 137 & $\begin{array}{c}\text { Abiotic depletion } \\
\text { potential-Elements }\end{array}$ & LCA methodology & $\mathrm{kg} \mathrm{Sb} \mathrm{eq.}$ \\
\hline 138 & $\begin{array}{c}\text { Abiotic depletion } \\
\text { potential-Fossil fuels }\end{array}$ & LCA methodology & $\mathrm{MJ}$ \\
\hline 150 & CAPEX & Ownership cost & $€$ \\
\hline 151 & OPEX & $\begin{array}{c}\text { Direct/explicit operation and } \\
\text { maintenance cost }\end{array}$ & $€$ \\
\hline
\end{tabular}

\section{Discussion and Conclusions}

The final goal of this paper was to develop a framework to support companies in assessing manufacturing activities using an inventory and impact perspective by retaining a corporate and production level view. Starting from previously developed frameworks and standards for eco-efficient manufacturing, the main focus was to develop an assessment methodology to explore production performance with the sustainability perspective.

From the environmental point of view, inventory indicators have been aligned with the GRI standards, thereby considering the following five dimensions of environmental sustainability: materials, energy, water, emissions, and waste. Instead, impact indicators have first been selected from the list provided by PEF and OEF, then filtered considering EPD.

Regarding the economic area, the most significant indicators are the cost (CAPEX and OPEX) and profitability indicators. When comparing before and after scenarios, in addition to cost indicators, a number of profitability KPIs can be calculated.

The breakdown structure used for clustering and identifying the lead indicators allows for straightforward application, readily adaptable to a variety of business cases.

Based on the framework classification matrix (Table 2) developed on the basis of the analysis carried out by Chofreh et al. [31], several gaps were identified. Most of the analyzed articles considered the area of environmental sustainability as a whole, without providing a separation between the production and corporate sides. Therefore, the majority of the frameworks lacked support for strategic, tactical, and operational activities, meaning that the top and mid-level management, along with the supervisory level, could not use sustainability information to support decision-making processes, resulting in limited relevance from an industrial perspective.

The scientific benefits of this research come from the conceptual validation with five industrial cases, meaning that the KPIs have been chosen according to industrial constraints such as applicability, calculous, and relevance. The framework includes different levels of indicators (inventory and impact) allowing for cross-sectoral use. The granularity and modularity of the proposed set permits the application of the framework, regardless of the production capacity, structure, and available resources of the company. The structure also allows for the understanding of the results by different levels of stakeholders, who, based on their skills, can use this information to make decisions.

The limitations of the applied methodologies lie in the fact that there may be the possibility that the framework cannot be applied to all firms, as it may require the input by experts or the use of advanced technologies for data collection. Additionally, given the 
diversity and large number of indicators considered, the framework could yield conflicting results, requiring the use of an expert to provide an interpretation.

Future research should be oriented towards confirming the proposed set of indicators for more aspects of the industrial domain, providing results for a quantitative validation. In addition, it would be appropriate to integrate into the framework a section dedicated to the circular economy and to extend the sustainability assessment rationales to the entire supply chain.

Author Contributions: Conceptualization, A.B., C.C., A.F., M.P., S.H., M.R., and T.U.; methodology, A.B., C.C., A.F., M.P., S.H., M.R., and T.U.; writing-original draft preparation, C.C and M.P.; writingreview and editing, A.B., C.C. A.F. and M.P.; visualization, C.C. and M.P.; supervision, A.B. and A.F.; All authors have read and agreed to the published version of the manuscript.

Funding: This research was funded by European Union's Horizon 2020 reseach and innovation program grant number 958339. The APC was funded by European Union's Horizon 2020 reseach and innovation program under grant agreement N 958339.

Institutional Review Board Statement: Not applicable.

Informed Consent Statement: Not applicable.

Data Availability Statement: Data sharing not applicable.

Acknowledgments: The work presented here was part of the Digital intelligence for collaborative Energy management in Manufacturing (DENIM) project that received funding from the European Union's Horizon 2020 research and innovation programme, under Grant Agreement N 958339.

Conflicts of Interest: The authors declare no conflict of interest.

\section{References}

1. Meet the 2020 Consumers Driving Change. Available online: https://www.ibm.com/thought-leadership/institute-businessvalue/report/consumer-2020 (accessed on 23 December 2021).

2. Bansard, J.; Schröder, M. International Institute for Sustainable Development Photo: NASA (CC0 1.0) STILL ONLY ONE EARTH: Lessons from 50 Years of UN Sustainable Development Policy the Sustainable Use of Natural Resources: The Governance Challenge Key Messages and Recommendations. 2021. Available online: https://www.iisd.org/articles/sustainable-use-naturalresources-governance-challenge (accessed on 23 December 2021).

3. Sustainable Manufacturing/US EPA. Available online: https://www.epa.gov/sustainability/sustainable-manufacturing (accessed on 27 December 2021).

4. Sustainable Manufacturing and Eco-Innovation: Towards A Green Economy; OECD Publications, 2009; Available online: https: //www.oecd.org/env/consumption-innovation/42957785.pdf (accessed on 23 December 2021).

5. Enablers and Barriers of Sustainable Manufacturing: Results from a Survey of Researchers and Industry Professionals $\mid$ Elsevier Enhanced Reader. Available online: https://reader.elsevier.com/reader/sd/pii/S2212827115000451?token=FF95A14AB4696F363 AC62CAC5826E88796F548D65E9D698D5F1EDD39FCE7C44D85E4E146E3201F38633A5CC41DFD9498\&originRegion=eu-west$1 \&$ originCreation=20220130142630 (accessed on 23 December 2021).

6. Hariyani, D.; Mishra, S. Organizational enablers for sustainable manufacturing and industrial ecology. Clean. Eng. Technol. 2022, 6, 100375. [CrossRef]

7. Yadav, G.; Kumar, A.; Luthra, S.; Garza-Reyes, J.A.; Kumar, V.; Batista, L. A framework to achieve sustainability in manufacturing organisations of developing economies using industry 4.0 technologies' enablers. Comput. Ind. 2020, 122, 103280. [CrossRef]

8. Why Is Sustainable Manufacturing So Important? Available online: https://www.rpo-manufacturing.com/blog/sustainablemanufacturing (accessed on 27 December 2021).

9. OECD Sustainable Manufacturing Indicators-OECD. Available online: https://www.oecd.org/innovation/green/toolkit/ oecdsustainablemanufacturingindicators.htm (accessed on 23 December 2021).

10. Sustainable Manufacturing Indicator Repository (SMIR) I NIST. Available online: https:/ /www.nist.gov/services-resources / software/sustainable-manufacturing-indicator-repository-smir\#: \{\}:text=The\%20Sustainable\%20Manufacturing\%20Indicator\% 20Repository,13\%20publicly\%20available\%20indicator\%20databases (accessed on 23 December 2021).

11. Sarkar, P.; Joung, C.B.; Carrell, J.; Feng, S.C. Sustainable manufacturing indicator repository. Proc. ASME Des. Eng. Tech. Conf. 2011, 2, 943-950. [CrossRef]

12. Single Market for Green Products-Environment-European Commission. Available online: https://ec.europa.eu/environment/ eussd/smgp/dev_methods.htm (accessed on 27 December 2021).

13. 2030 Climate Target Plan. Available online: https://ec.europa.eu/clima/eu-action/european-green-deal/2030-climate-targetplan_en (accessed on 27 December 2021). 
14. $\mathrm{CO}_{2}$ and Greenhouse Gas Emissions-Our World in Data. Available online: https://ourworldindata.org/co2-and-othergreenhouse-gas-emissions (accessed on 27 December 2021).

15. Peruzzini, M.; Pellicciari, M. Models of impact for sustainable manufacturing. Adv. Transdiscipl. Eng. 2016, 4, 145-154. [CrossRef]

16. Brundage, M.P.; Chang, Q.; Li, Y.; Arinez, J.; Xiao, G. Sustainable Manufacturing Performance Indicators for a Serial Production Line. IEEE Trans. Autom. Sci. Eng. 2016, 13, 676-687. [CrossRef]

17. Amrina, E.; Yusof, S.M. Key performance indicators for sustainable manufacturing evaluation in automotive companies. In Proceedings of the 2011 IEEE International Conference on Industrial Engineering and Engineering Management, Singapore, 6-9 December 2011; pp. 1093-1097. [CrossRef]

18. May, G.; Taisch, M.; Prabhu, V.V.; Barletta, I. Energy related key performance indicators-state of the art, gaps and industrial needs. IFIP Adv. Inf. Commun. Technol. 2013, 414, 257-267. [CrossRef]

19. Kara, S.; Honke, I.; Kaebernick, H. An integrated framework for implementing sustainable product development. In Proceedings of the Fourth International Symposium on Environmentally Conscious Design and Inverse Manufacturing, Eco Design, Tokyo, Japan, 12-14 December 2005; Volume 2005, pp. 684-691. [CrossRef]

20. Koplin, J.; Seuring, S.; Mesterharm, M. Incorporating sustainability into supply management in the automotive industry-the case of the Volkswagen AG. J. Clean. Prod. 2007, 15, 1053-1062. [CrossRef]

21. Vachon, S.; Klassen, R.D. Environmental management and manufacturing performance: The role of collaboration in the supply chain. Int. J. Prod. Econ. 2008, 111, 299-315. [CrossRef]

22. Herrmann, C.; Zein, A.; Thiede, S.; Bergmann, L.; Bock, R. Bringing sustainable manufacturing into practice-the machine tool case. In Proceedings of the 6th Global Conference on Sustainable Production Development and Life Cycle Engineering, Busan, Korea; pp. 272-277. Available online: https://ris.utwente.nl/ws/portalfiles/portal/228163559/Herrmann2008bringing.pdf (accessed on 22 December 2021).

23. Ladd, S.; Badurdeen, F. Supplier sustainability evaluation and selection. In Proceedings of the 2010 Industrial Engineering Research Conference, Cancun, Mexico, 5-9 June 2010; pp. 1-6.

24. El-Haggar, S.M. Sustainability of Industrial Waste Management. En: Sustainable Industrial Design and Waste Management. J. Environ. Prot. 2017, 8. Available online: https://www.scirp.org/(S(lz5mqp453edsnp55rrgjct55))/reference/referencespapers. aspx?referenceid=1999031 (accessed on 30 June 2021).

25. Bae, H.; Smardon, R.S. Indicators of Sustainable Business Practices. Available online: www.intechopen.com (accessed on 22 December 2021).

26. ISO-ISO 14040:2006—Environmental Management_Life Cycle Assessment_Principles and Framework. Available online: https:/ / www.iso.org/standard/37456.html (accessed on 30 June 2021).

27. ISO. ISO 15663 Petroleum, Petrochemical and Natural Gas Industries_Life Cycle Costing; Published by International Organization for Standardization; 2021; Available online: www.iso.org (accessed on 15 December 2021).

28. IEC. IEC 60300-3-3: Application Guide_Life Cycle Costing; International Electrotechnical Commission, 2017; Available online: https: / / webstore.iec.ch/publication/31206 (accessed on 28 December 2021).

29. ISO. ISO 15686-5:2017-Buildings and Constructed Assets-Service Life Planning-Part 5: Life-Cycle Costing. Available online: https:/ / www.iso.org/standard/61148.html (accessed on 28 December 2021).

30. Hoogmartens, R.; van Passel, S.; van Acker, K.; Dubois, M. Bridging the gap between LCA, LCC and CBA as sustainability assessment tools. Environ. Impact Assess. Rev. 2014, 48, 27-33. [CrossRef]

31. Chofreh, A.G.; Goni, F.A. Review of Frameworks for Sustainability Implementation. Sustain. Dev. 2017, 25, 180-188. [CrossRef]

32. Winroth, M.; Almström, P.; Andersson, C. Sustainable indicators at factory level-a framework for practical assessement. In Proceedings of the IIE Annual Conference. Proceedings. Institure of Industrial and Systems Engineers (IISE), Orlando, FL, USA, 19-22 May 2012; Available online: https:/ / research.chalmers.se/publication/155756 (accessed on 23 December 2021).

33. Huang, A.; Badurdeen, F. Sustainable Manufacturing Performance Evaluation: Integrating Product and Process Metrics for Systems Level Assessment. Procedia Manuf. 2017, 8, 563-570. [CrossRef]

34. Shuaib, M.; Seevers, D.; Zhang, X.; Badurdeen, F.; Rouch, K.E.; Jawahir, I.S. Product sustainability index (ProdSI): A metrics-based framework to evaluate the total life cycle sustainability of manufactured products shuaib. Prodsi framework to evaluate product sustainability. J. Ind. Ecol. 2014, 18, 491-507. [CrossRef]

35. Tan, H.X.; Yeo, Z.; Ng, R.; Tjandra, T.B.; Song, B. A sustainability indicator framework for Singapore small and medium-sized manufacturing enterprises. Procedia CIRP 2015, 29, 132-137. [CrossRef]

36. Donnelly, A.; Jones, M.; O'Mahony, T.; Byrne, G. Selecting environmental indicator for use in strategic environmental assessment. Environ. Impact Assess. Rev. 2007, 27, 161-175. [CrossRef]

37. Hristov, I.; Chirico, A. The role of sustainability key performance indicators (KPIs) in implementing sustainable strategies. Sustainability 2019, 11, 5742. [CrossRef]

38. Park, K.; Kremer, G.E.O. Text mining-based categorization and user perspective analysis of environmental sustainability indicators for manufacturing and service systems. Ecol. Indic. 2017, 72, 803-820. [CrossRef]

39. Fan, C.; Carrell, J.D.; Zhang, H.C. An investigation of indicators for measuring sustainable manufacturing. In Proceedings of the 2010 IEEE International Symposium on Sustainable Systems and Technology, Arlington, VA, USA, 17-19 May 2010. [CrossRef]

40. Lucato, W.C.; Santos, J.C.d.; Pacchini, A.P.T. Measuring the sustainability of a manufacturing process: A conceptual framework. Sustainability 2018, 10, 81. [CrossRef] 
41. Joung, C.B.; Carrell, J.; Sarkar, P.; Feng, S.C. Categorization of indicators for sustainable manufacturing. Ecol. Indic. 2013, 24, 148-157. [CrossRef]

42. Tarquinio, L.; Raucci, D.; Benedetti, R. An investigation of Global Reporting Initiative performance indicators in corporate Sustainability Reports: Greek, Italian and Spanish evidence. Sustainability 2018, 10, 897. [CrossRef]

43. GRI Standards. Available online: https://www.globalreporting.org/standards / (accessed on 30 June 2021).

44. STANDARD, G.R.I. GRI-301-Materials-2016. Available online: https://www.globalreporting.org/standards/media/2130/italiangri-301-materials-2016.pdf (accessed on 23 December 2021).

45. STANDARD, G.R.I. GRI-302-Energy-2016. Available online: https://www.globalreporting.org/standards/media/2131/italiangri-302-energy-2016.pdf (accessed on 23 December 2021).

46. STANDARD, G.R.I. GRI-303-Water-2018. Available online: https://www.globalreporting.org/standards/media/1909/gri-303water-and-effluents-2018.pdf (accessed on 23 December 2021).

47. STANDARD, G.R.I. GRI-305-Emissions-2016. Available online: https://www.globalreporting.org/standards/media/1012/gri305-emissions-2016.pdf (accessed on 23 December 2021).

48. STANDARD, G.R.I. GRI-306-Waste-2020. Available online: https://www.globalreporting.org/standards/media/2573/gri-306waste-2020.pdf/ (accessed on 23 December 2021).

49. Errigo, A.; Choi, J.K.; Kissock, K. Techno-Economic-Environmental impacts of industrial energy assessment: Sustainable industrial motor systems of small and medium-sized enterprises. Sustain. Energy Technol. Assess. 2022, 49, 101694. [CrossRef]

50. Menghi, R.; Papetti, A.; Germani, M.; Marconi, M. Energy efficiency of manufacturing systems: A review of energy assessment methods and tools. J. Clean. Prod. 2019, 240, 118276. [CrossRef]

51. Mousavi, S.; Kara, S.; Kornfeld, B. A hierarchical framework for concurrent assessment of energy and water efficiency in manufacturing systems. J. Clean. Prod. 2016, 133, 88-98. [CrossRef]

52. Arvidsson, R.; Svanström, M. A framework for energy use indicators and their reporting in life cycle assessment. Integr. Environ. Assess. Manag. 2016, 12, 429-436. [CrossRef]

53. Mayer, F.D.; Brondani, M.; Carrillo, M.C.V.; Hoffmann, R.; Lora, E.E.S. Revisiting energy efficiency, renewability, and sustainability indicators in biofuels life cycle: Analysis and standardization proposal. J. Clean. Prod. 2020, 252, 119850. [CrossRef]

54. Coroiu, M.; Chindris, M. Energy efficiency indicators and methodology for evaluation of energy performance and retained savings. In Proceedings of the 49th International Universities Power Engineering Conference (UPEC), Cluj-Napoca, Romania, 2-5 September 2014.

55. Wu, L.-M.; Chen, B.-S. Modeling of energy efficiency indicator for semiconductor industry. In Proceedings of the 2007 IEEE International Conference on Industrial Engineering and Engineering Management, Singapore, 2-4 December 2007. [CrossRef]

56. Thiede, S. Energy Efficiency in Manufacturing Systems; Springer Science \& Business Media: Berlin, Germany, 2012. [CrossRef]

57. PEF and OEF: Assessment of Environmental Performance of Products, Services and Organisations-IMQ. Available online: https: //www.imq.it/en/green-services-and-solutions/assessment-of-environmental-performance-pef-and-oef-solutions (accessed on 2 July 2021).

58. Pelletier, N.; Allacker, K.; Manfredi, S.; Chomkhamsri, K.; de Souza, D.M. Organisation Environmental Footprint (OEF) Guide Institute for Environment and Sustainability (IES) Organisation Environmental Footprint Guide-CONSOLIDATED VERSION Organisation Environmental Footprint Guide. 2012. Available online: https://ec.europa.eu/environment/eussd/pdf/footprint/OEF\%20Guide_ final_July\%202012_clean\%20version.pdf (accessed on 2 December 2021).

59. Manfredi, S.; Allacker, K.; Chomkhamsri, K.; Pelletier, N.; de Souza, D.M. Product Environmental Footprint (PEF) Guide Institute for Environment and Sustainability (IES) Product Environmental Footprint Guide, Consolidated Version; 2012. Available online: https: / / ec.europa.eu/environment/eussd/pdf/footprint/PEF\%20methodology\%20final\%20draft.pdf (accessed on 28 December 2021).

60. EPD International. Available online: https://www.environdec.com/home (accessed on 2 July 2021).

61. ISO. ISO 14025:2006-Environmental Labels and Declarations-Type III Environmental Declarations-Principles and Procedures Available online: https:/ / www.iso.org/standard/38131.html (accessed on 28 December 2021).

62. The PCR I EPD International. Available online: https:/ / www.environdec.com/product-category-rules-pcr/the-pcr (accessed on 28 December 2021).

63. Linke, B.S.; Corman, G.J.; Dornfeld, D.A.; Tönissen, S. Sustainability indicators for discrete manufacturing processes applied to grinding technology. J. Manuf. Syst. 2013, 32, 556-563. [CrossRef]

64. Amrina, E.; Vilsi, A.L. Key Performance Indicators for Sustainable Manufacturing Evaluation in Cement Industry. Procedia CIRP 2015, 26, 19-23. [CrossRef]

65. Patil, H.R.; Channappa; Javalagi, M. Analysis of Key Performance Indicators for Sustainable Manufacturing in Sugar Industry Using Analytical Hierarchy Process. Indian J. Eng. Mater. Sci. (IJEMS) 2020, 27, 959-963.

66. Akbar, M.; Irohara, T. Scheduling for sustainable manufacturing: A review. J. Clean. Prod. 2018, 205, 866-883. [CrossRef]

67. Daniela, M.K.; Pigosso, C.A.; McAloone, T.C. Towards the ex-ante sustainability screening of circular economy initiatives in manufacturing companies: Consolidation of leading sustainability-related performance indicators. J. Clean. Prod. 2019, 241, 118318. [CrossRef]

68. Andersson, E.; Thollander, P. Key performance indicators for energy management in the Swedish pulp and paper industry. Energy Strategy Rev. 2019, 24, 229-235. [CrossRef] 
69. Dočekalová, M.P.; Kocmanová, A. Composite indicator for measuring corporate sustainability. Ecol. Indic. 2016, 61, 612-623. [CrossRef]

70. Zarte, M.; Pechmann, A.; Nunes, I.L. Indicator framework for sustainable production planning and controlling. Int. J. Sustain. Eng. 2019, 12, 149-158. [CrossRef]

71. Kocmanova, A.; Docekalova, M.P.; Simanaviciene, Z. Corporate sustainability measurement and assessment of Czech manufacturing companies using a composite indicator. Eng. Econ. 2017, 28, 88-100. [CrossRef]

72. Steffen, W.; Noone, K.J. Planetary Boundaries: Exploring the Safe Operating Space for Humanity [Internet] UNLOCKUnderstanding Local Government Drivers for Sustainable Consumption View Project Climate Adaptation Governance in a Globalising World View Project, 960. Available online: https://www.researchgate.net/publication/284146060 (accessed on 23 December 2021).

73. Bey, N. Life Cycle Management. Life Cycle Assess. Theory Pract. 2018, 519-544. [CrossRef] 